\title{
A GUIDE TO THE MEPS-IC GOVERNMENT LIST SAMPLE MICRODATA
}

\author{
by
}

\author{
Alice Zawacki * \\ U.S. Bureau of the Census
}

CES 11-27

September, 2011

The research program of the Center for Economic Studies (CES) produces a wide range of economic analyses to improve the statistical programs of the U.S. Census Bureau. Many of these analyses take the form of CES research papers. The papers have not undergone the review accorded Census Bureau publications and no endorsement should be inferred. Any opinions and conclusions expressed herein are those of the author(s) and do not necessarily represent the views of the U.S. Census Bureau. All results have been reviewed to ensure that no confidential information is disclosed. Republication in whole or part must be cleared with the authors.

To obtain information about the series, see www.census.gov/ces or contact Cheryl Grim, Editor, Discussion Papers, U.S. Census Bureau, Center for Economic Studies 2K130B, 4600 Silver Hill Road, Washington, DC 20233, CES.Papers.List@census.gov. 


\begin{abstract}
The Medical Expenditure Panel Survey-Insurance Component (MEPS-IC) is conducted to provide nationally representative estimates on employer sponsored health insurance. MEPSIC data are collected from private sector employers, as well as state and local governments. While similar information is gathered from these two sectors, differences in the survey process exist. The goal of this paper is to provide details on the public sector including types of state and local government employers, sample design, general information on the data collected in the MEPS-IC, and additional sources of information.
\end{abstract}

JEL codes: Health (I1); Wages, Compensation, and Labor costs (J3); Firm Behavior: Empirical Analysis (D22)

Keywords: employer sponsored insurance; state and local governments; Medical Expenditure Panel Survey-Insurance Component; public sector

* The author would like to thank Marleen Livesay, Beth Capps, Jim Branscome, Erika Becker Medina, Lucia Foster, and Kristin McCue for their reviews and helpful comments. Any opinions and conclusions expressed herein are those of the author and do not necessarily represent the views of the U.S. Census Bureau. All results have been reviewed to ensure that no confidential information is disclosed. 
2. STATE AND LOCAL GOVERNMENTS 6

2.1. Definitions 6

2.2. Governments Integrated Directory (GID) 6

$\begin{array}{ll}\text { 2.3. Classification of local governments } & 7\end{array}$

$\begin{array}{ll}\text { 2.3.1. County governments } & 7\end{array}$

2.3.2. Municipal and township governments 8

$\begin{array}{ll}\text { 2.3.3. Special districts } & 8\end{array}$

2.3.4. School district governments and public school systems 9

3. SURVEY METHODS 9

3.1. Sampling 9

3.1.1. Establishments 9

$\begin{array}{ll}\text { 3.1.2. } & \text { Changes in sample design } \\ & 10\end{array}$

$\begin{array}{lll}\text { 3.1.2.1. } & \text { Original sample design (1996-2003) } & 10\end{array}$

3.1.2.2. Updates to sample design (2003) 11

3.1.3. Health insurance plans 11

3.2. Data collection 12

$\begin{array}{ll}\text { 3.3. Data processing } & 13\end{array}$

4. TECHNICAL INFORMATION 13

$\begin{array}{lll}\text { 4.1. Data files } & 13\end{array}$

$\begin{array}{ll}\text { 4.2. Identification variables } & 14\end{array}$

5. VARIABLE NOTES 15

$\begin{array}{lll}\text { 5.1. Keycodes and associated variables } & 15\end{array}$

$\begin{array}{lll}\text { 5.2. } & \text { Employment } & 15\end{array}$

$\begin{array}{lll}\text { 5.3. } & \text { Retirees } & 16\end{array}$

5.4. Geocodes 16 
6. ACCESSING AND USING MICRODATA

$\begin{array}{ll}\text { 7. ADDITIONAL SOURCES OF INFORMATION } & 17\end{array}$

$\begin{array}{ll}\text { 7.1. } & \text { Methodology reports } \\ \end{array}$

$\begin{array}{ll}\text { 7.2. Statistical briefs } & 18\end{array}$

7.3. MEPS Summary data tables 19

7.4. MEPSnet/IC Query tools $\quad 19$

$\begin{array}{ll}\text { REFERENCES } & 20\end{array}$

LIST OF TABLES

Table 1.1. $\quad$ Number of employees in private sector and state and local governments (2009) 21

Table 1.2. Ranking of state and local government functions by full-time equivalent employment (2009) 22

Table 2.1. $\quad$ MEPS-IC Sample of government units 24

$\begin{array}{lll}\text { Table 2.2. } & \text { Special district functions }\end{array}$

Table 3.1 Sampling of MEPS-IC government list sample $\quad 26$

Table 3.2. Types of government units in the MEPS-IC 27

\section{LIST OF FIGURES}

Figure 2.1. Full-time equivalent employment (in thousands) of state and

$\begin{array}{ll}\text { local governments by type of government } & 28\end{array}$

Figure 2.2. Monthly payrolls of state and local governments by type of government (million dollars)

\section{APPENDICES}

A. 2010 MEPS-IC Government unit questionnaire: Part I (11F) 30

B. 2010 MEPS-IC Government unit questionnaire: Part II (11R) 34

C. 2010 MEPS-IC Government plan information questionnaire (11S) 40 


\section{MEDICAL EXPENDITURE PANEL SURVEY-INSURANCE COMPONENT}

The Medical Expenditure Panel Survey-Insurance Component (MEPS-IC) ${ }^{1}$ is conducted to provide nationally representative estimates on employer sponsored health insurance. The survey is sponsored by the Agency for Healthcare Research and Quality and collected annually by the U.S. Census Bureau. MEPS-IC data are collected from private sector employers, as well as state and local governments. ${ }^{2}$ While similar information is gathered from these two sectors, differences in the survey process exist. The goal of this paper is to provide details on the public sector including types of state and local government employers, sample design, general information on the data collected in the MEPS-IC, and additional sources of information. ${ }^{3}$

The MEPS-IC collects data from employers on whether or not they offer health insurance to workers. If health insurance is offered, detailed health insurance plan information is collected. In addition, data are collected on the characteristics of employers as well as on the characteristics of workers. The data are available for 1996-2006 and 2008-2010. ${ }^{4}$ In the 2007 Census of Governments, 89,526 state and local governments existed compared to over 6 million establishments in the Census Bureau's Business Register listing of private sector establishments.

This paper describes the organization of state and local governments and information available in the MEPS-IC for these employers. Table 1.2 ranks state and local government functions by employment and education tops each list. In 2009 according to the MEPS-IC, there are over 16.2 million enrollees covered by employer-sponsored health insurance plans offered by state and local governments with total costs of hospitalization and physician service health plans exceeding \$148.5 million.

\footnotetext{
${ }^{1}$ For more information about MEPS and other components, visit http://meps.ahrq.gov/mepsweb/about_meps/survey_back.jsp.

${ }^{2}$ Note: the MEPS-IC does not collect data on health insurance benefits offered to Federal employees.

${ }^{3}$ Many researchers often inquire about the relationship between the household and insurance components of MEPS and the ability to link together data from each. Non-nationally representative linked data is available for select years. For more information, visit http://meps.ahrq.gov/mepsweb/data_stats/download_data/pufs/link_99hcic/hc_ic99link_doc.shtml. Researchers interested in combining household data on employees with employer information have also used statistical matching techniques. For an example of research using statistically matched data from the MEPS household and insurance components, see Selden and Gray, 2006.

${ }^{4}$ Data were not collected in 2007 when the survey design changed from retrospective (calendar year following survey year) to current year data collection (calendar year same as survey year). For example, under the new design, 2010 data is made available in 2011 with private list sample files processed earlier in the year than the government list sample files.
} 


\section{STATE AND LOCAL GOVERNMENTS}

\subsection{Definitions}

In order to be counted as a government unit by the Census Bureau, the entity must have all three of the following attributes (U.S. Census Bureau, 2002):

(1) Existence as an organized entity: presence of some organizational form and possession of some corporate powers (e.g., perpetual succession, right to sue and be sued, have a name, make contracts, acquire and dispose of property, and similar provisions)

(2) Governmental Character: officers of the entity are popularly elected or appointed by public officials and public accountability (i.e., requirements for public reporting or for accessibility of records to public inspection)

(3) Substantial Autonomy: entity has substantial fiscal and administrative independence, subject to statutory limitations and any supervision of local governments by the state

\subsection{Governments Integrated Directory (GID)}

The Census Bureau conducts a census of governments every 5 years (i.e., in years ending with a “2” or “7”). In addition to public employment and government finances, this census also covers government organization. During the government organization phase of the census of governments, research is conducted to update the master list of governments in the U.S., which is called the Governments Integrated Directory (GID). In 2007, 89,476 local government units were included in this master list. ${ }^{5}$ The GID is used by the Census Bureau for its government statistical programs to account for all public sector financial and employment activity without omission or duplication. The GID also serves as the sampling frame for various surveys.

The GID provides information on the name of the government unit, a unique identification code, and other reference information ${ }^{6}$ about all local governments and dependent school systems in the U.S. ${ }^{7}$ This master list is updated periodically to add new government units and remove

\footnotetext{
${ }^{5}$ A map showing the number of local governments by county is available "2007 Census of Governments: The Many Layers of American Government” at http://www.census.gov/govs/pubs/presentations brochures.html. A table showing this information is available at http://www.census.gov/govs/cog/GovOrgTab03ss.html. For more information on the structure and list of governments visit http://www.census.gov/govs/go/index.html.

${ }^{6}$ The following reference information is also provided: type of government, title, first line of mailing address, city mailing address, postal 2-digit state abbreviation, mailing address 5-digit zip code, web site address, population, and state and county Federal Information Processing Standard (FIPS) codes.

${ }^{7}$ State-level data and information on different types of governments and school systems from the 2007 Governments Integrated Directory is available at http://harvester.census.gov/gid/gid_07/options.html
} 
dissolved or inactive units. ${ }^{8}$ The process for updating the GID varies by type of government unit (see classifications below) and is carried out continuously between censuses (U.S. Census Bureau, 2009). The list of general purpose government units are updated based on information from various sources including the annual Boundary and Annexation Survey conducted by the Census Bureau's Geography Division. The list of public school systems is updated using a directory maintained by the U.S. Department of Education, National Center for Education Statistics. Special district governments are updated using a variety of sources including reviews of state legislation on the creation or authorization of these types of units, lists of special district governments published by federal, state, and private sources, contact with state and local officials, review of state and local taxation information, and election results related to the universe of special districts. The GID is also adjusted based on information from various other annual government surveys and censuses including the Local Government Directory Survey which includes data on the characteristics of special districts (e.g., functional activities, manner for selection of elected officials, and their legal basis for existence).

While the GID includes all governments and therefore does not have quality issues related to sampling errors, limitations do exist related to nonsampling error. These types of errors include nonresponse, misclassification of governments, incorrect reporting, coverage errors, and inaccurate coding of data. The Census Bureau reviews questionnaires for completeness and accuracy and tabulated data to minimize nonsampling errors (U.S. Census Bureau, 2002).

\subsection{Classification of local governments}

The Census Bureau recognizes 5 types of local governments. Three of these are considered general-purpose governments and include counties, municipalities, and townships. The remaining 2 classifications of local governments are special districts and school districts. Governments are structured differently in different states and governments' responsibilities and authority can vary from state to state as well as within a state. ${ }^{9}$ Table 2.1 shows the breakdown of the MEPS-IC sample by government type.

\subsubsection{County governments}

Organized county governments exist in 48 states in the U.S., but are not found in Connecticut, Rhode Island, or the District of Columbia. 3,033 county governments existed in 2007 including the county governments officially designated as "parish" governments in Louisiana and "borough" governments in Alaska (U.S. Census Bureau, 2002). Not all counties have a county government and when county and municipal governments are consolidated or merged, the unit is counted as a municipal government in Census Bureau statistics.

\footnotetext{
${ }^{8}$ A government unit is considered inactive if it has no activity, receives no revenue, and has no officers currently (U.S. Census Bureau, 2002).

${ }^{9}$ For more information on the structure of governments, visit http://govsit/govs/go/index.html
} 


\subsubsection{Municipal and township governments}

These two sub-county general-purpose governments are distinguished primarily by the historical details surrounding their incorporation. 19,492 municipal governments and 16,519 town or township governments were classified in the 2007 Census of Governments (U.S. Census Bureau, 2009). While historical circumstances distinguish these 2 types of local government units, their powers and functions are similar in many states (especially in the Northeast). The scope of their services, however, can differ from state to state and within the same state.

Municipal governments are local governments given authority through state constitutions and statutes. The purpose of these units is to provide general government for defined areas, including governments designated as cities, boroughs (except in Alaska), towns, ${ }^{10}$ and villages. Township governments also receive authorization from state constitutions and statutes and provide general government for towns and townships in 20 states. In 11 of these states, overlap exists in the areas served by municipalities and town or township governments. $^{11}$

\subsubsection{Special districts}

Special districts are independent, special-purpose governments that are separate entities with substantial administrative and fiscal independence from general purpose governments. Local government units that are classified as special districts exclude school district governments. Many entities classified as special districts are called districts or authorities ${ }^{12}$ and perform either a single function or several (often related) types of services.

Governments set up special districts for various reasons: to meet regional needs when state and local governments do not coincide with geographical boundaries, to address a specific issue when the local government lacks the financial and/or administrative resources, to exert taxing or revenue powers local governments face limits, to meet special needs with revenue collections and service provision of an area, and to focus on one specific function with specialized personnel, knowledge, technology, or procedures

\footnotetext{
${ }^{10}$ Except in the 6 New England states, Minnesota, New York, and Wisconsin (U.S. Census Bureau, 2002).

${ }^{11}$ All municipal governments in Indiana operate within territories that are also served by town or township governments. Some municipal governments in the following states operate in territories also served by towns or township governments: Connecticut, Illinois, Kansas, Michigan, Minnesota, Missouri, Nebraska, New York, Ohio, and Vermont. No geographic overlapping exists between these two types of government units in Maine, Massachusetts, New Hampshire, New Jersey, North Dakota, Pennsylvania, Rhode Island, South Dakota, and Wisconsin. (U.S. Census Bureau 2009)

12 Many “districts” or “authorities” are closely related to the three general purpose government units or state governments, however, and therefore classified as subordinate agencies of those governments and not counted as separate special district governments (U.S. Census Bureau 2009)
} 
(U.S. Census Bureau Governments Division, April 2004). Examples of services provided by special districts include hospitals and fire protection, but also mosquito abatement and cemetery upkeep. See Table 2.2 for a listing of functions.

\subsubsection{School district governments and public school systems}

The 2007 count of governments includes 13,051 independent school districts. The 1,510 “dependent” public school systems are not counted as separate governments in 2007 but as agencies of other state, county, municipal, or town or township governments (U.S. Census Bureau, 2009). School organization varies greatly through the U.S., because of differences in state legislative provisions. In 2007, 31 states provided for public schools solely through independent school districts. Fifteen states have independent school districts operating public schools providing elementary and secondary education and operated elsewhere by county, municipal, town or township, or state governments in other areas. Four states and the District of Columbia have no independent school systems.

Figures 2.1 and 2.2 show full-time equivalent employment and monthly payrolls by type of government respectively.

\section{SURVEY METHODS}

\subsection{Sampling}

\subsubsection{Establishments}

The MEPS-IC collects data on state and local governments sampled from the Census Bureau's Census of Governments, which is conducted every 5 years. While the household component of MEPS has a panel design, the insurance component of MEPS is a repeated cross sectional design. Table 3.1 shows the corresponding year of the Census of Governments for each year of the MEPS-IC sample. Overall, about 8 percent of the MEPS-IC government list sample is represented by state governments and the balance or 92 percent are local government units.

Across survey years, the average number of sampled government units is about 2,500. The government component of the MEPS-IC will consist of approximately 1,800 state and local governmental entities and also their associated dependent agencies (e.g., libraries, school boards, community colleges, etc.). ${ }^{13,14}$ "Government" is used to mean a

\footnotetext{
${ }^{13}$ Dependent agencies are added to the GID only if the parent government does not provide the data. Dependent agencies possess governmental character but not substantial autonomy. For purposes of Census Bureau statistics, "government character" relates primarily to public administration or to provisions for public accountability or public authority rather than the functions or activities performed (U.S. Census Bureau Governments Division, April 2004). That is, dependent government agencies are governed by the state. Classification of the dependent agencies determines if they are dependent on the state or a local government or governments. Some states have no dependent government agencies and only have state level government agencies.
} 
parent agency along with all its dependent agencies and "unit" refers to parent agencies or dependent agencies. A parent agency may or may not have dependent agencies. The MEPS-IC sample is roughly 70 percent state and local "parent" government units and 30 percent dependent units. Dependent agencies include various activities such as school systems, universities, utilities, toll highways, hospitals (U.S. Census Bureau, 2002).

The sample of government units is comprised of 4 types of cases and Table 3.2 provides a breakdown by the MEPS-IC variable GOV_CERT:

1. Government certainty cases: include the 51 state governments (including Washington, D.C.) and any local/municipal government whose full-time equivalent (FTE) is greater than 5,000 employees. About 400 certainty government units are in the MEPS-IC sample each year. ${ }^{15}$

2. Zero or missing full-time equivalent employment cases: a separate sample is drawn from these cases. These units are included because they may have employees. The zero value may be an error or employees may have been added since the Census of Governments was taken. ${ }^{16}$

3. Non-certainty cases: these local governments are subject to the sampling process, which underwent changes over time. See details below.

4. All dependent agencies of selected cases

\subsubsection{Changes in sample design ${ }^{17}$}

\subsubsection{Original sample design (1996-2003) (Sommers, 1999a)}

From 1996 until 2003, the government list sample was comprised of 2 parts, certainty governments with more than 5,000 full-time equivalent employees and a sample of smaller governments allocated so that governments in smaller states were oversampled relative to those in larger states. This oversampling was done in both the private and public sectors in order to produce estimates at the state and national level for all employers - both public and private. The sample allocation within states was divided between the public and private sector based upon each sector's proportion of total state employment.

\footnotetext{
${ }^{14}$ Unless prohibited by state law, a dependent government agency can offer a health plan that differs from the parent state's health plan.

${ }^{15}$ Note that estimates based on these certainty cases will have a standard error of zero.

${ }^{16}$ In 2010, zero full-time equivalent cases were not sampled and a sample of 40 units from those with missing fulltime equivalent employment was included.

${ }^{17}$ The following two reports discuss the original and subsequent changes to the MEPS-IC sample design: "List Sample Design of the 1996 Medical Expenditure Panel Survey Insurance Component” ( Sommers, 1999a) and “Updates to the Medical Expenditure Panel Survey Insurance Component List Sample Design, 2004” (Sommers, 2007a).
} 
The sample selection for the private and government frames was conducted independently and within each sector the sample was further allocated to individual strata. Governments not selected with certainty were stratified by the State in which the government was located and size (number of employees). Final selections used stratified sequential sampling.

\subsubsection{Updates to sample design (2003) (Sommers, 2007b)}

Sampling of establishments in the MEPS-IC underwent changes that were fully implemented in the 2004 survey. Knowledge gained from conducting the MEPSIC survey since 1996 led to an updating of the sample design, including the development of a new government sample completely independent of the private list sample design or allocation.

As before, all state governments and local governments with more than 5,000 full-time equivalent employees are still defined as certainty sample units. Final allocation provides for total national allocations and Census Division allocations similar to those in earlier survey years. Allocations for noncertainty governments within Census Divisions now, however, are proportional to government employment in each state to improve published estimates at the national and Census Division level. That is, the sample is now allocated within each state between the public and private sectors based upon each sector's proportion of total state employment.

A sample allocation of 200 noncertainty governments for each census division was established in 2003 and has not changed since then. That is, rather than using states as strata as in the original design, now the noncertainty cases are stratified by the 9 census divisions ${ }^{18}$ and no further certainties are selected. The sample is selected from the noncertainty population by using a modified probability proportional to size sampling methodology.

\subsubsection{Health insurance plans}

The MEPS-IC asks government respondents to provide information on all health insurance plans offered to employees. ${ }^{19}$ While over 90 percent of state and local government employers offer fewer than 12 plans, some offer more than 20 health plans. Information on all offered health plans is collected for certainty governments, whether reported via returned mail surveys or telephone follow-up. If non-certainty governments

\footnotetext{
${ }^{18}$ The 9 census divisions are New England, Middle Atlantic, East North Central, West North Central, South Atlantic, East South Central, West South Central, Mountain, and Pacific. Listing of states included in each division are available at www.census.gov/geo/www/us_regdiv.pdf

${ }^{19}$ In some years, however, data were collected via mailed surveys on up to 4 plans for non-certainty governments.
} 
do not provide their information via the mailed survey and data are collected using telephone follow-up, then data are reported on up to 3 health plans.

\subsection{Data collection}

MEPS-IC data on state and local governments are collected and compiled using a variety of methods. These processes include mailing out survey forms to employers, web collection, and brochure extraction. Mail and telephone follow-up is used to obtain data from employers if respondents do not respond to initial requests.

The MEPS-IC survey instruments for collecting data from state and local government units can be viewed online at http://meps.ahrq.gov/mepsweb/survey comp/survey ic.jsp and copies are also provided in Appendices A and B. Separate forms are used to collect information on the employer depending on whether they are a certainty government (Form 11C) or a non-certainty government (Form 11). Similarly, form 11CS collects plan-level information from certainty governments and form 11S is used for noncertainty government units.

The MEPS-IC also collects data on health insurance offerings to retirees. Data collection for state and local government employers is collected on different forms. Form 11CR collects data on retirees from certainty governments and form 11R collects data from non-certainty governments.

Additionally, web-based versions of the MEPS-IC forms are now used for collecting data from certainty and non-certainty governments. ${ }^{20}$ More than half of the certainty governments report online. Originally, the web-based versions mimicked the appearance of the paper forms described above and now the web-based data collection forms do not look like the paper forms (e.g., do not show skip patterns). ${ }^{21}$ Information on both employer characteristics and workforce characteristics (Form 11C), health plan data (Form 11CS), and retiree data (Form 11CR) are reported via web collection.

Certainty government units will also provide copies of health insurance brochures (e.g., brochures are uploaded to the Internet) or Internet links to their brochure information in response to the MEPS-IC request for plan information. In the past, data collection was accomplished using a web-based brochure extract compilation process. Now the data are keyed to worksheets and converted to a data entry format.

\footnotetext{
${ }^{20}$ Some respondents prefer to respond through the mail rather than through mail collection.

${ }^{21}$ For example on the $11(\mathrm{~S})$ plan form, respondents are asked if the health plan is self-insured. If the plan is purchased from an insurance underwriter or the respondent does not know, the respondent skips question 6 and proceeds to question 7.
} 


\subsection{Data processing}

After data are collected, they are processed through a number of steps. First the data are put through editing programs, which identify missing, inconsistent, or out-of-range values for particular items and perform "logical" edits. An example of a logical edit is a case in which the respondent may not answer whether or not health insurance is offered, but the employer does provide information on the characteristics of one or more health plans. In this case, filling in a "yes" response to whether or not the employer offers health insurance appears logical.

The next step in data processing is imputation to fill in missing values. Hot deck imputation procedures ${ }^{22}$ are used for the MEPS-IC and data users should check the availability of imputed data for variables of interest, since additional measures have been added to the imputation process over the years of the survey. The data files contain 2 measures for variables that are imputed: (1) the reported value of measures and (2) the reported data with missing values filled in with imputed data (see Section 5. Variable notes). ${ }^{23}$

The MEPS-IC contains weights for respondents for both establishment- and plan-level analyses. The weights are adjusted to sufficiently represent all nonrespondents and subgroups, including subgroups with response rates differing from the survey's average (see Sommers, 1999b). Note that the parent certainty cases (i.e., state and large local governments) described above are assigned a sample weight (SAMPWGT) of 1.0.

\section{TECHNICAL INFORMATION}

\subsection{Data files}

While the MEPS-IC collects employer-sponsored health insurance information from employers in both the private sector and in state and local governments, the data files for the sectors are kept separate. As mentioned above, the files for private employers are released earlier than the files for state and local government units. The variables are similar in the 2 sets of files, but some variables hold data relevant for the private sector and therefore are missing data for public employers. Similarly, some measures are only relevant to the government sector (see Section 5. Variable notes).

MEPS-IC data collected from state and local governments is maintained in 4 separate SAS datafiles:

(1) Data on the employer and its workforce collected on forms 11 and 11C are located in an "establishment” file: MepXXXXgovestab.sas7bdat

\footnotetext{
${ }^{22}$ See Cox and Cohen (1985), Kalton and Kasprzyk (1986), and Stiller and Dalzell (1997).

${ }^{23}$ Additional information on imputation of the MEPS-IC is available in (Sommers 2007a) and (Sommers, 2000).
} 
(2) Data containing specific health plan information collected on forms 11S and 11CS is located in a "plan” file: MepXXXXgovplan.sas7bdat

(3) Information written on forms submitted by respondents is placed in a "remarks" file: MepXXXXgovrmrk.sas7bdat

(4) Data collection efforts are reported for sampled employers who did not respond to the MEPS-IC are contained in the "nonresponse" files: MepXXXXgovnrsp.sas7bdat

where XXXX=4-digit year, 1996-2006 and 2008-2009.

\subsection{Identification variables}

Data from the different files can be merged together using identifiers provided in each of the MEPS-IC government list sample files. The variables ID, ID_CD, and PLANT are used to merge the health plan information to the establishment. These three variables uniquely identify each government unit in both the establishment and plan files.

\begin{tabular}{|l|c|c|c|c|c|c|}
\hline & \multicolumn{3}{|c|}{ ID } & ID_CD & PLANT \\
Position & $1-2$ & 3 & $4-6$ & $7-9$ & 10 & (2 digits) \\
\hline Reference & State & Type & County & Place & Government & $\begin{array}{c}\text { (5 digits) } \\
\text { '00000' if parent government } \\
\text { if a dependent government } \\
\text { unit }\end{array}$ \\
\hline
\end{tabular}

As noted above, ID is a 9-digit identifier with the first 2 digits indicating the state. The digit in the third position refers to the type of government unit and can take a value from 0 to 5 as follows:

$$
\begin{array}{ll}
0 & =\text { state } \\
1 & =\text { county } \\
2 & =\text { municipality } \\
3 & =\text { township } \\
4 & =\text { special district } \\
5 & =\text { school district }
\end{array}
$$


Positions 4-6 of the ID provides a 3-digit county code. The last 3 digits of ID refer to a unit code, which identifies a specific government and are assigned within the state, county, and type of government.

In the MEPS-IC government list sample files, ID_CD is always equal to ' 1 ' to indicate a government unit.

PLANT is a 5-digit code and indicates the dependent unit within a parent government. For example, a school which is a dependent government unit would have a PLANT value other than '00000'. For example, four sampled units may share the same ID such as '012345678' but each may have a different value for PLANT such as '12345', '01234', '23456' and '00000.' The case with PLANT equal to '00000' indicates this information is for the parent and the other observations with the same ID and PLANT not equal to '00000' indicates the dependents within that same state or parent government.

The MEPS-IC plan file also contains an identifier PART_CD in addition to the 3 identifiers described above. PART_CD refers to the plan record within the same employer and takes values from '01' up to the number of health plans reported for the employer. For example, an employer who offers four health plans will have PART_CD values 01-04.

\section{VARIABLE NOTES}

\subsection{Keycodes and associated variables}

"Keycodes" refer to the 3-digit number assigned to each data item on the MEPS-IC survey form. For example, on the 11(S) questionnaire (see copy in Appendix C) under Section B: General plan information, question 2 asks: Which type of health care provider was available through this plan? Next to the response boxes for different provider arrangements is the keycode "103." Variable names are C\#\#\#, where \#\#\# stands for the keycode. In this example, the keycode is C103 and will take categorical value 1, 2, or 3 depending on the type of health care provider.

If imputations are made for a keycode, an I\#\#\# variable will be associated with it. The I\#\#\# variable will hold the reported or original or edited response in some cases and the imputed value in other cases. Additional variables have been added to the imputation process in some survey years. Note also that some keycodes are dropped from the survey over time and new measures are added periodically.

\subsection{Employment}

The MEPS-IC government list sample files contain a number of different measures related to employment: 
GOV_FTE = full-time government employment (i.e., the parent agency and all its dependent agencies)

EMP_CY = employment for the unit (i.e., parent or dependent agency) for the current year

EMP_PY = employment for the unit (i.e., parent or dependent agency) for the previous year

C200 = employment for unit (i.e., parent or dependent agency). C200 is not asked on the questionnaire but taken from administrative records during the editing stage of data processing. Generally C200=EMP_CY.

EMP_CY_ENT = employment for the government (i.e., the parent agency and all its dependent agencies) for the current year

EMP_PY_ENT = employment for the government (i.e., the parent agency and all its dependent agencies) for the previous year

GOV_EMP_PT = part-time employees at the unit (i.e., parent or dependent agency)

GOV_EMP_PT_PAR = part-time employees at the parent agency

C203 = part-time employees at the unit (i.e., parent or dependent agency). C203 is not collected on forms, rather the value is taken from administrative records during the edit stage.

In addition to these employment measures, data are available on the percent of workers who are female, 50+ years of age, belong to a union, and earn a low, medium, or high wage. The wage thresholds are changed in some years to reflect changes in wages in the labor market.

\subsection{Retirees}

A copy of the 2010 Form 11(R) is provided in Appendix B and shows that 2 pages of the survey questionnaire are devoted to questions on retirees. Since the beginning of the MEPS-IC survey, questions about retiree eligibility have been asked for retirees under the age of 65 and retirees 65 or more years of age. Questions on enrollment, premiums, and contributions were asked about all retirees regardless of age until 2000, when the questions were redesigned to ask for data on retirees less than 65 separately from retirees 65 years of age and older.

\subsection{Geocodes}

The MEPS-IC government list sample establishment file contains address information for each government unit. For example, the street, city, state, and 9-digit zip code of the unit's physical location is included as well as the street, city, state, and 9-digit zip code in 
the mailing address for the unit. The file also contains the state's FIPS code (STATE_FIPS).

\section{ACCESSING AND USING MICRODATA}

A number of summary data tables are available on the AHRQ webpage for MEPS and are discussed below in Section 7. Additional Sources of Information (http://meps.ahrq.gov/mepsweb/data_stats/quick tables.jsp). These aggregate statistics are presented for the 9 Census divisions and by government type (state or local) and local government size (categories: less than 250; 250-999; 1,000-4,999; 5,000-9,999; or 10,000+ employees). Researchers, however, can apply for access to the microdata files to answer questions that cannot be addressed with the publicly available tables. The microdata files provide geographic detail, specific information about the type of government (county, municipality, town/township, special district, school district), and the exact number of employees. In addition, users have detailed information on health plan characteristics, as well as employer and workforce characteristics not provided in the aggregate data. Individuals interested in accessing the microdata can learn more by visiting the webpage for the Center for Economic Studies at the U.S. Census Bureau, http://www.census.gov/ces/rdcresearch/.

\section{ADDITIONAL SOURCES OF INFORMATION}

\subsection{Methodology Reports}

Sommers, J. P. Updates to the Medical Expenditure Panel Survey Insurance Component List Sample Design, 2004. Methodology Report No. 18. January 2007. Agency for Healthcare Research and Quality, Rockville, Md. http://www.meps.ahrq.gov/mepsweb/data_files/publications/mr18/mr18.pdf

Sommers, J. P. Additional Imputations of Employer Information for the Insurance Component of the Medical Expenditure Panel Survey since 1996. Methodology Report No. 17. January 2007. Agency for Healthcare Research and Quality, Rockville, Md. http://meps.ahrq.gov/mepsweb/data_stats/Pub_ProdResults_Details.jsp?pt=Methodology+Report $\underline{\text { \&opt }=2 \& \mathrm{id}=799}$

Sommers, J.P. Estimation of Expenditures and Enrollments for Employer-Sponsored Health Insurance. Rockville, MD: Agency for Healthcare Research and Quality; 2002. MEPS Methodology Report No. 14. AHRQ Pub. No. 03-0009. http://www.meps.ahrq.gov/mepsweb/data_files/publications/mr14/mr14.pdf

Sommers, J.P. Imputation of Employer Information for the 1996 Medical Expenditure Panel Survey Insurance Component. Rockville, MD: Agency for Healthcare Research and Quality; 2000. MEPS Methodology Report No. 10. AHRQ Pub. No. 00-0039. http://www.meps.ahrq.gov/mepsweb/data_files/publications/mr10/mr10.pdf

Sommers, J.P. Construction of Weights for the 1996 Medical Expenditure Panel Survey Insurance Component List Sample. Rockville, MD: Agency for Healthcare Research and 
Quality; 1999. MEPS Methodology Report No. 8. AHCPR Pub. No. 00-0005. http://www.meps.ahrq.gov/mepsweb/data_files/publications/mr8/mr8.pdf

Sommers, J.P. List Sample Design of the 1996 Medical Expenditure Panel Survey Insurance Component. Rockville, MD: Agency for Healthcare Research and Quality; 1999. MEPS Methodology Report No. 6. AHCPR Pub. No. 99-0037. http://www.meps.ahrq.gov/mepsweb/data_files/publications/mr6/mr6.pdf

\subsection{Statistical Briefs}

Crimmel, B.L. Employer-Sponsored Health Insurance for Employees of State and Local Governments, by Census Division, 2009. Statistical Brief \#302. December 2010. Agency for Healthcare Research and Quality, Rockville, MD. http://www.meps.ahrq.gov/mepsweb/data_files/publications/st302/stat302.pdf

Crimmel, B.L. Employer-Sponsored Health Insurance for Employees of State and Local Governments, by Census Division,2008. Statistical Brief \#273. December 2009. Agency for Healthcare Research and Quality, Rockville, MD.

http://www.meps.ahrq.gov/mepsweb/data_files/publications/st273/stat273.pdf

Crimmel, B.L. and Sommers, J. P. Employer-Sponsored Health Insurance for State and Local Governments, by Census Division, 2006. Statistical Brief \#223. Agency for Healthcare Research and Quality, Rockville, MD, http://meps.ahrq.gov/mepsweb/data_stats/Pub_ProdResults_Details.jsp?pt=Statistical+Brief\&opt $=2 \&$ id $=879$

Sommers, J. P. Co-pays, Deductibles, and Coinsurance Percentages for Employer-Sponsored Health Insurance in the State and Local Government Workforce, by Census Division, 2007. Statistical Brief \#185. September 2007. Agency for Healthcare Research and Quality, Rockville, Md. http://www.meps.ahrq. gov/mepsweb/data_files/publications/st185/stat185.pdf

Sommers, J. P. Employer-Sponsored Health Insurance for State and Local Governments, by Census Division, 2005. Statistical Brief \#184. September 2007. Agency for Healthcare Research and Quality, Rockville, Md.

http://www.meps.ahrq.gov/mepsweb/data_files/publications/st184/stat184.pdf

Sommers, J. P. Co-pays, Deductibles, and Coinsurance Percentages for Employer-Sponsored Health Insurance in the Non-Federal Workforce, by Industry Classification, 2005. Statistical Brief \#182. August 2007. Agency for Healthcare Research and Quality, Rockville, Md. http://meps.ahrq.gov/mepsweb/data_stats/Pub_ProdResults_Details.jsp?pt=Statistical+Brief\&opt $=2 \& \mathrm{id}=826$

Sommers, J. P. Co-pays, Deductibles, and Coinsurance Percentages for Employer-Sponsored Health Insurance in the Non-Federal Workforce, by Industry Classification, 2004. Statistical Brief \#145. October 2006. Agency for Healthcare Research and Quality, Rockville, Md. http://meps.ahrq.gov/mepsweb/data_stats/Pub_ProdResults_Details.jsp?pt=Statistical+Brief\&opt $=2 \& \mathrm{id}=781$ 
Sommers, J. Employee Copays and Deductibles for Employer-Sponsored Health Insurance in 1999 and 2002. Statistical Brief \#53. September 2004. Agency for Healthcare Research and Quality, Rockville, MD. http://meps.ahrq.gov/mepsweb/data files/publications/st53/stat53.pdf

\subsection{MEPS Summary data tables}

These can be accessed by going to

http://www.meps.ahrq.gov/mepsweb/data stats/quick tables search.jsp?component=2\&subcomp onent $=1$. After selecting the year of interest, the public sector table series can be selected. The tables are also organized into subseries: employees, premiums/contributions/enrollments, deductibles/copayments/coinsurance, and distributional percentiles of costs. In addition to accessing the tables from this webpage, visitors can also read helpful technical notes and survey documentation (http://www.meps.ahrq.gov/mepsweb/survey_comp/ic_technical_notes.shtml).

\subsection{MEPSnet/IC Query Tools}

This query tool is based on aggregate statistics and provides statistics and trends in employersponsored health insurance. Using a step-by-step process, visitors can obtain national and regional health insurance estimates for State and local governments. MEPSnet/IC can be accessed through http://www.meps.ahrq.gov/mepsweb/data_stats/MEPSnetIC.jsp. 


\section{REFERENCES}

Cox, B. G. and Cohen, S. B. (1985) Methodological Issues for Health Care Surveys. New York, NY: Marcel Dekker.

Kalton, G. and Kasprzyk, D. (1986) "The treatment of missing survey data." Survey Methodology, Statistics Canada, Vol. 12, No 1, pp 1-16.

Selden, T.M. and B.M. Gray. 2006. "Tax subsidies for employment-related health insurance: estimates for 2006," Health Affairs 25 (November-December, 2006): 1568-1579.

Sommers, J. P. 2007a. Additional Imputations of Employer Information for the Insurance Component of the Medical Expenditure Panel Survey since 1996. Methodology Report No. 17. January 2007. Agency for Healthcare Research and Quality, Rockville, Md. http://meps.ahrq.gov/mepsweb/data_stats/Pub_ProdResults_Details.jsp?pt=Methodology+Report \&opt=2\&id=799 .

Sommers, J. P. 2007b. Updates to the Medical Expenditure Panel Survey Insurance Component List Sample Design, 2004. Methodology Report No. 18. Agency for Healthcare Research and Quality, Rockville, Md. http://www.meps.ahrq.gov/mepsweb/data_files/publications/mr18/mr18.pdf.

Sommers, J.P. 2000. Imputation of Employer Information for the 1996 Medical Expenditure Panel Survey Insurance Component. Rockville, MD: Agency for Healthcare Research and Quality; 2000. MEPS Methodology Report No. 10. AHRQ Pub. No. 00-0039. http://www.meps.ahrq.gov/mepsweb/data_files/publications/mr10/mr10.pdf.

Sommers, J.P. 1999a. List Sample Design of the 1996 Medical Expenditure Panel Survey Insurance Component. Rockville, MD: Agency for Healthcare Research and Quality; MEPS Methodology Report No. 6. AHCPR Pub. No. 99-0037. http://www.meps.ahrq.gov/mepsweb/data_files/publications/mr6/mr6.pdf.

Sommers, JP. 1999b. “Construction of weights for the 1996 Medical Expenditure Panel Survey Insurance Component list sample.” Rockville, MD: Agency for Health Care Policy and Research; 1999. MEPS Methodology Report No. 8. AHCPR Pub. No. 00-0005. http://meps.ahrq.gov/mepsweb/data_stats/Pub_ProdResults_Details.jsp?pt=Methodology+Report \&opt=2\&id=41.

Stiller, J and Dalzell, D. (1997) "Hot-deck imputation with SAS arrays and macros for large surveys." Proceedings of the 10th Annual NESUG Conference, North East SAS Users Group, pp 709-714.

U.S. Census Bureau. 2009. "Lists and Structure of Governments: How the Data are Collected." http://www.census.gov/govs/go/how_data_collected.html.

U.S. Census Bureau. 2002. 2002 Census of Governments, Volume 1, Number 1, Government Organization, GC02(1)-1, U.S. Government Printing Office, Washington, DC, 2002. 
Table 1.1. Number of employees in private sector and state and local governments (2009)

\begin{tabular}{|c|c|c|}
\hline Number of employees & $\begin{array}{l}\text { Private sector } \\
\text { (standard error) }\end{array}$ & $\begin{array}{c}\text { State and local governments } \\
\text { (standard error) }\end{array}$ \\
\hline Full-time & $\begin{array}{l}87,721,498 \\
(1,082,341)\end{array}$ & $\begin{array}{l}15,122,484 \\
(120,661)\end{array}$ \\
\hline Part-time & $\begin{array}{l}22,798,497 \\
(268,260)\end{array}$ & $\begin{array}{l}4,479,859 \\
(95,476)\end{array}$ \\
\hline Total & $\begin{array}{l}110,519,995 \\
(1,090,007)\end{array}$ & $\begin{array}{l}19,602,343 \\
(173,204)\end{array}$ \\
\hline
\end{tabular}

Source: Agency for Healthcare Research and Quality, Medical Expenditure Panel Survey-Insurance Component. Tables I.B.1., I.B.3., and I.B.4. for the private sector and III.B.1., III.B.3. and III.B.4. for state and local governments.

http://meps.ahrq.gov/mepsweb/data_stats/summ_tables/insr/national/series_1/2009/tib1.htm http://meps.ahrq.gov/mepsweb/data_stats/summ_tables/insr/national/series_1/2009/tib3.htm http://meps.ahrq.gov/mepsweb/data_stats/summ_tables/insr/national/series_1/2009/tib4.htm http://meps.ahrq.gov/mepsweb/data_stats/summ_tables/insr/national/series_3/2009/tiiib1.htm http://meps.ahrq.gov/mepsweb/data_stats/summ_tables/insr/national/series_3/2009/tiiib3.htm http://meps.ahrq.gov/mepsweb/data_stats/summ_tables/insr/national/series_3/2009/tiiib4.htm

\footnotetext{
${ }^{24}$ Preliminary employment estimates for state and local governments are produced early in the year and later revised by the U.S. Census Bureau. Estimates may differ from those presented here.
} 
Table 1.2. Ranked state \& local government functions by full-time equivalent employment (2009)

\begin{tabular}{|c|c|c|c|c|c|}
\hline STATE & $\begin{array}{c}\text { Full-time } \\
\text { equivalent } \\
\text { employment }\end{array}$ & $\begin{array}{c}\text { Percent of } \\
\text { total full- } \\
\text { time } \\
\text { equivalent } \\
\text { employment }\end{array}$ & LOCAL & $\begin{array}{c}\text { Full-time } \\
\text { equivalent } \\
\text { employment }\end{array}$ & $\begin{array}{c}\text { Percent of } \\
\text { total full- } \\
\text { time } \\
\text { equivalent } \\
\text { employment }\end{array}$ \\
\hline $\begin{array}{l}\text { Higher } \\
\text { education }\end{array}$ & $1,673,771$ & $38.05 \%$ & $\begin{array}{l}\text { Elementary \& } \\
\text { secondary } \\
\text { education }\end{array}$ & $6,884,042$ & $55.48 \%$ \\
\hline Corrections & 484,426 & $11.01 \%$ & $\begin{array}{l}\text { Police } \\
\text { protection }\end{array}$ & 848,069 & $6.83 \%$ \\
\hline Hospitals & 417,553 & $9.49 \%$ & Hospitals & 584,993 & $4.71 \%$ \\
\hline Public welfare & 241,999 & $5.50 \%$ & Fire protection & 348,610 & $2.81 \%$ \\
\hline Highways & 235,496 & $5.35 \%$ & $\begin{array}{l}\text { Higher } \\
\text { education }\end{array}$ & 346,988 & $2.80 \%$ \\
\hline $\begin{array}{l}\text { All other and } \\
\text { unallocable }\end{array}$ & 192,725 & $4.38 \%$ & Highways & 306,517 & $2.47 \%$ \\
\hline Health & 184,424 & $4.19 \%$ & Public welfare & 284,189 & $2.29 \%$ \\
\hline $\begin{array}{l}\text { Judicial and } \\
\text { legal }\end{array}$ & 178,602 & $4.06 \%$ & $\begin{array}{l}\text { All other and } \\
\text { unallocable }\end{array}$ & 268,322 & $2.16 \%$ \\
\hline $\begin{array}{l}\text { Financial } \\
\text { Administration }\end{array}$ & 169,066 & $3.84 \%$ & Corrections & 267,105 & $2.15 \%$ \\
\hline $\begin{array}{l}\text { Natural } \\
\text { resources }\end{array}$ & 145,342 & $3.30 \%$ & Health & 254,803 & $2.05 \%$ \\
\hline $\begin{array}{l}\text { Police } \\
\text { protection }\end{array}$ & 106,017 & $2.41 \%$ & $\begin{array}{l}\text { Judicial and } \\
\text { legal }\end{array}$ & 252,783 & $2.04 \%$ \\
\hline $\begin{array}{l}\text { Other } \\
\text { education }\end{array}$ & 87,281 & $1.98 \%$ & $\begin{array}{l}\text { Parks and } \\
\text { recreation }\end{array}$ & 242,024 & $1.95 \%$ \\
\hline $\begin{array}{l}\text { Social } \\
\text { insurance } \\
\text { administration }\end{array}$ & 80,760 & $1.84 \%$ & $\begin{array}{l}\text { Financial } \\
\text { Administration }\end{array}$ & 231,999 & $1.87 \%$ \\
\hline $\begin{array}{l}\text { Other } \\
\text { government } \\
\text { administration }\end{array}$ & 56,739 & $1.29 \%$ & $\begin{array}{l}\text { Other } \\
\text { government } \\
\text { administration }\end{array}$ & 231,181 & $1.86 \%$ \\
\hline $\begin{array}{l}\text { Elementary \& } \\
\text { secondary } \\
\text { education }\end{array}$ & 52,975 & $1.20 \%$ & Transit & 208,747 & $1.68 \%$ \\
\hline $\begin{array}{l}\text { Parks and } \\
\text { recreation }\end{array}$ & 34,048 & $0.77 \%$ & Water supply & 172,666 & $1.39 \%$ \\
\hline Transit & 32,429 & $0.74 \%$ & Local libraries & 136,902 & $1.10 \%$ \\
\hline
\end{tabular}


Table 1.2. Ranked state \& local government functions by full-time equivalent employment (2009) continued

\begin{tabular}{|c|c|c|c|c|c|}
\hline STATE & $\begin{array}{c}\text { Full-time } \\
\text { equivalent } \\
\text { employment }\end{array}$ & $\begin{array}{l}\text { Percent of } \\
\text { total full- } \\
\text { time } \\
\text { equivalent } \\
\text { employment }\end{array}$ & LOCAL & $\begin{array}{c}\text { Full-time } \\
\text { equivalent } \\
\text { employment }\end{array}$ & $\begin{array}{l}\text { Percent of } \\
\text { total full- } \\
\text { time } \\
\text { equivalent } \\
\text { employment }\end{array}$ \\
\hline $\begin{array}{l}\text { State liquor } \\
\text { stores }\end{array}$ & 8,177 & $0.19 \%$ & Sewerage & 127,946 & $1.03 \%$ \\
\hline $\begin{array}{l}\text { Water } \\
\text { transport and } \\
\text { terminals }\end{array}$ & 5,076 & $0.12 \%$ & $\begin{array}{l}\text { Housing and } \\
\text { community } \\
\text { development }\end{array}$ & 114,282 & $0.92 \%$ \\
\hline $\begin{array}{l}\text { Electric } \\
\text { power }\end{array}$ & 4,106 & $0.09 \%$ & $\begin{array}{l}\text { Solid waste } \\
\text { management }\end{array}$ & 111,341 & $0.90 \%$ \\
\hline $\begin{array}{l}\text { Air } \\
\text { transportation }\end{array}$ & 3,105 & $0.07 \%$ & $\begin{array}{l}\text { Electric } \\
\text { power }\end{array}$ & 76,195 & $0.61 \%$ \\
\hline $\begin{array}{l}\text { Solid waste } \\
\text { management }\end{array}$ & 1,994 & $0.05 \%$ & $\begin{array}{l}\text { Air } \\
\text { transportation }\end{array}$ & 45,118 & $0.36 \%$ \\
\hline Sewerage & 1,761 & $0.04 \%$ & $\begin{array}{l}\text { Natural } \\
\text { resources }\end{array}$ & 42,183 & $0.34 \%$ \\
\hline Water supply & 754 & $0.02 \%$ & Gas supply & 12,305 & $0.10 \%$ \\
\hline Libraries & 564 & $0.01 \%$ & $\begin{array}{l}\text { Water } \\
\text { transport and } \\
\text { terminals }\end{array}$ & 8,132 & $0.07 \%$ \\
\hline $\begin{array}{l}\text { Fire } \\
\text { protection }\end{array}$ & 0 & $0.00 \%$ & $\begin{array}{l}\text { Social } \\
\text { insurance } \\
\text { administration }\end{array}$ & 477 & $0.00 \%$ \\
\hline $\begin{array}{l}\text { Housing and } \\
\text { community } \\
\text { development }\end{array}$ & 0 & $0.00 \%$ & $\begin{array}{l}\text { State liquor } \\
\text { stores }\end{array}$ & 0 & $0.00 \%$ \\
\hline Gas supply & 0 & $0.00 \%$ & $\begin{array}{l}\text { Other } \\
\text { education }\end{array}$ & 0 & $0.00 \%$ \\
\hline
\end{tabular}

Source: 2009 Annual Survey of Public Employment and Payroll. U.S. Census Bureau. 
Table 2.1. MEPS-IC Sample of government units

\begin{tabular}{|c|c|c|c|}
\hline Value of GOV_TYPE & Description & $\begin{array}{l}\text { Percent employers } \\
\text { (weighted) }\end{array}$ & $\begin{array}{c}\text { Percent of employees } \\
\text { (weighted) }\end{array}$ \\
\hline 0 & state & $0.29 \%$ & $27.19 \%$ \\
\hline 1 & county & $8.41 \%$ & $16.30 \%$ \\
\hline 2 & municipality & $28.55 \%$ & $15.48 \%$ \\
\hline 3 & township & $18.35 \%$ & $2.47 \%$ \\
\hline 4 & special district & $24.16 \%$ & $4.19 \%$ \\
\hline 5 & school district & $20.24 \%$ & $34.38 \%$ \\
\hline
\end{tabular}

Source: 2009 MEPS-IC government list sample establishment files. Agency for Healthcare Research and Quality. 


\title{
Table 2.2. Special District Functions
}

\author{
Air Transportation \\ Elementary and Secondary Education \\ Local Fire Protection \\ Health \\ Hospitals \\ Highways \\ Housing and Community Development \\ Libraries (applies to the state of Hawaii, only) \\ Natural Resources \\ Parks and Recreation \\ Police Protection \\ Public Welfare \\ Sewerage \\ Solid Waste Management \\ Sea and Inland Port Facilities \\ Other and Unallocable \\ Water Utilities \\ Electric Utilities \\ Gas Utilities \\ Transit Utilities
}

Source: U.S. Census Bureau, 2006 Government Finance and Employment Classification Manual, October 2006. http://www.census.gov/govs/www/06classificationmanual/06 gfe classmanual toc.html 
Table 3.1. Sampling of MEPS-IC government list sample

\begin{tabular}{|c|c|}
\hline MEPS-IC Survey year & Census of Governments year \\
\hline 1996 & 1992 \\
\hline $1997-2001$ & 1997 \\
\hline $2002-2006$ & 2002 \\
\hline $2008-2011$ & 2007 \\
\hline
\end{tabular}


Table 3.2. Types of government units in the MEPS-IC

\begin{tabular}{|c|c|c|}
\hline $\begin{array}{c}\text { Value of } \\
\text { GOV_CERT }\end{array}$ & Description & $\begin{array}{c}\text { Percentage of } \\
\text { sample } \\
\text { (weighted) }\end{array}$ \\
\hline 0 & Certainties (parents and dependents) & $1.21 \%$ \\
\hline 1 & $\begin{array}{l}\text { Value discontinued with } 2010 \text { MEPS-IC survey year. In earlier } \\
\text { years GOV_CERT=1 indicated that the state had their sample size } \\
\text { increased (i.e., some states requested that their sample size be } \\
\text { increased beyond that allocated per the sample design) }\end{array}$ & $\begin{array}{l}\text { Generally very } \\
\text { small }\end{array}$ \\
\hline 2 & Noncertainty parents; sampled unit & $89.91 \%$ \\
\hline 3 & Zero or missing full-time equivalent cases & $2.12 \%$ \\
\hline 5 & $\begin{array}{l}\text { Noncertainty dependents; if added to have complete coverage of a } \\
\text { government unit }\end{array}$ & $6.76 \%$ \\
\hline
\end{tabular}

Source: 2009 MEPS-IC government list sample establishment files. Agency for Healthcare Research and Quality. 
Figure 2.1. Full-time equivalent employment (in thousands) of state and local governments by type of government

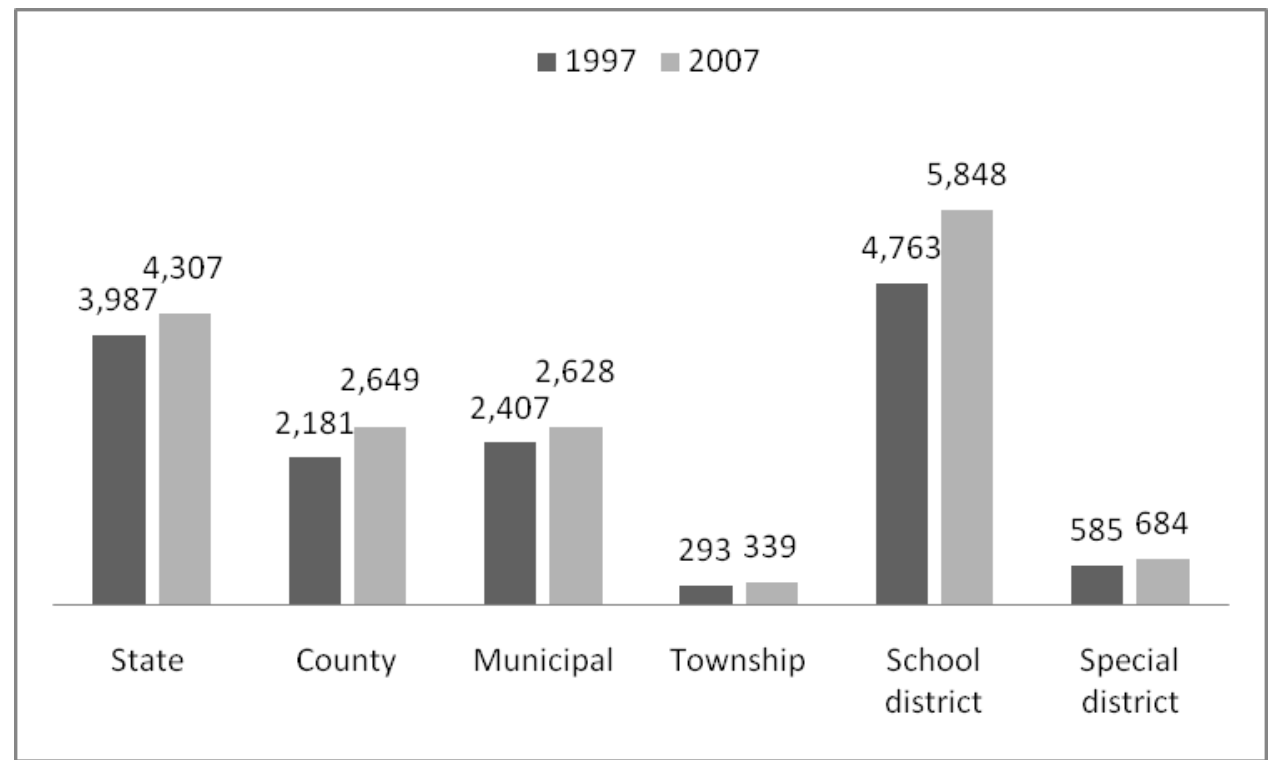

Source: 1997 and 2007 Census of Government Employment. U.S. Census Bureau. http://www.census.gov/govs/apes/historical_data_2007.html 
Figure 2.2. Monthly payrolls of state and local governments by type of government (million dollars)

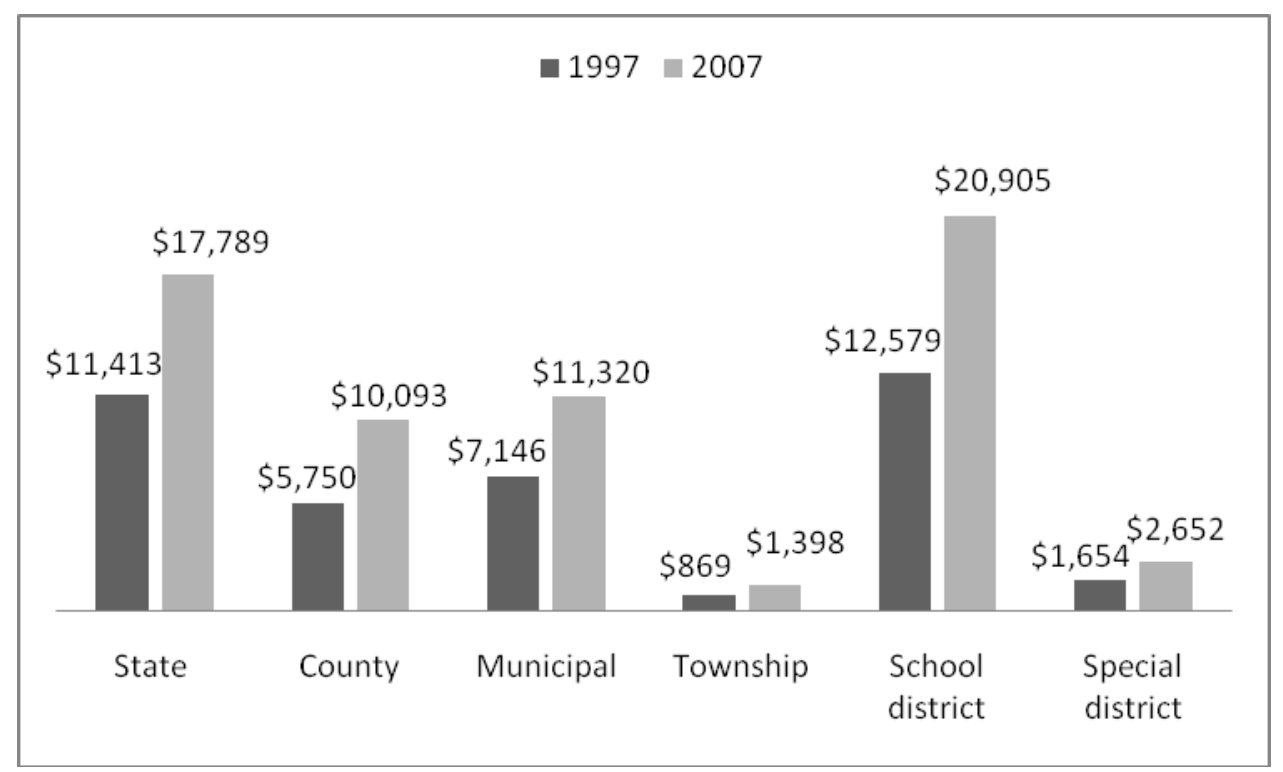

Source: 1997 and 2007 Census of Government Employment. U.S. Census Bureau. http://www.census.gov/govs/apes/historical_data_2007.html 
Appendix A. Health Insurance Cost Study:

2010 Government Unit Questionnaire (11F) 


\section{Medical Expenditure Panel Survey Insurance Component \\ HEALTH INSURANCE COST STUDY Government Questionnaire}

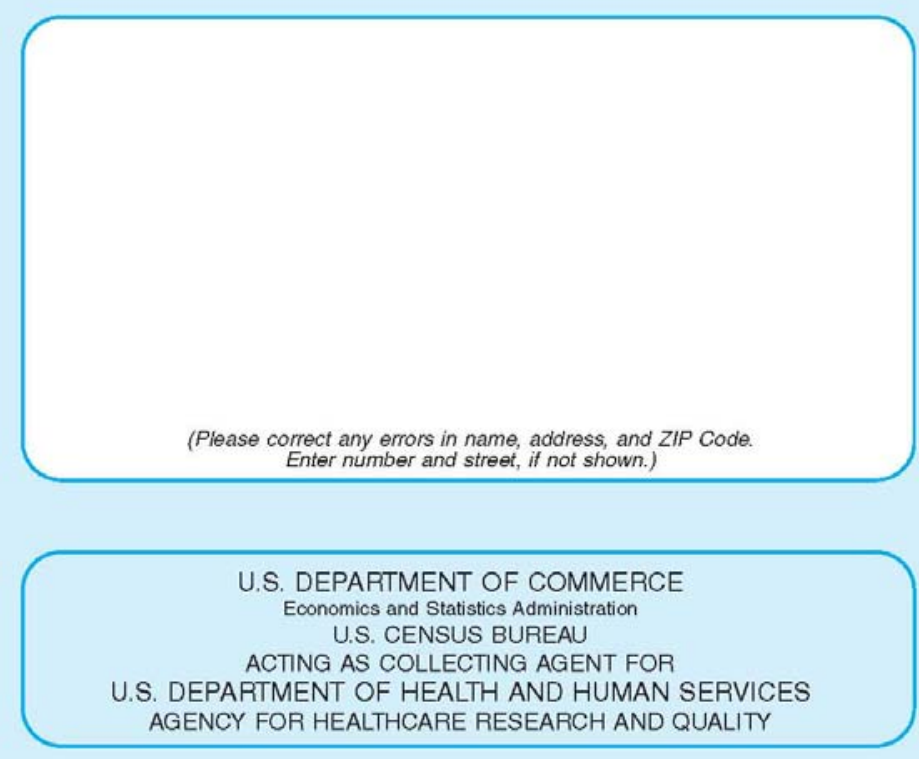

INTERNET RESPONSE

You may respond to this survey via the Internet at the following web address: http://respond.census.gov/meps11 Your Survey Key to access the Internet form is:

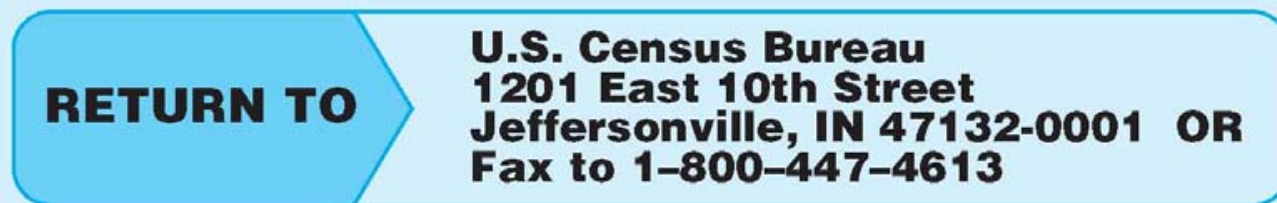

PLEASE RETURN ENTIRE PACKAGE WITHIN

PLEASE DO NOT REMOVE THIS COVER SHEET

FOFM MEPS-1 1(F) (04-07-2010) Dratt 6 


\section{INSTRUCTIONS}

1. Please report for the government unit identified on the cover sheet.

2. Please report data for the year 2010.

3. Estimates are acceptable.

4. For an explanation of unfamiliar terms, refer to the definition sheet included with this package.

5. Unless otherwise specified, respond for ACTIVE employees.

6. Please retain a completed copy of this form for your records.

7. If you have any questions or need assistance in completing the questionnaire, please call 1-888-273-3878.

We are conducting this study under the authority of Section 913 of the Public Health Service Act (Title 42, United States Code (U.S.C.), Section 299b-2). Sections 924c and 308d of that Act (42 U.S.C. Section $299 \mathrm{c}-3$ (c) and 42 U.S.C. Section $242 \mathrm{~m}$, respectively) ensure that the information you report will be released only to authorized staff of the Census Bureau, the Agency for Healthcare Research and Quality, and their authorized researchers and contractors.

\section{Paperwork Reduction Act and Burden Statements}

We expect that it will take 45 minutes, on average, to complete the basic questionnaire. If you offered more than one plan, we expect it will take an additional 10 minutes per plan, on average. In addition, we estimate that it will take 15 minutes to review the instructions and locate the requested information. You may send any comments regarding this burden estimate or any other aspect of the collection of information, including suggestions for reducing burden, to the following address: Director, Center for Financing. Access and Cost Trends. Paperwork Reduction Project 0935-0110. Agency for Healthcare Research and Quality.

Room 5030, 540 Gaither Road, Rockville, MD 20850. Please do not mail questionnaires to this address as it will delay data processing. 


\section{Section A - NUMBER OF PLANS}

Please respond for the government unit identified on the cover sheet unless otherwise specified.

Respond for ACTIVE employees only.

1a. Did your government unit make available or contribute to the cost of any health insurance plans for its ACTIVE employees in 2010?

For this survey, a health insurance plan is hospital and/or physician coverage made available to employees.

b. How many different health insurance choices did your government unit make available or contribute to for its ACTIVE employees during the 2010 plan year?

Do not count single service plans (optional plans) such as dental or vision.

Plans offered by the same insurance company which offer:

- Single, employee-plus-one, and family coverage

providing the same level of benefits count as ONE

plan.

- High and standard options count as TWO plans.

- An $\mathrm{HMO}$ and a conventional plan from the same insurance company count as TWO plans.
001

$\square$ Yes - Continue with Question $1 b$

$2 \square$ No - SKIP to MEPS-11(R), Section C, Question 1

003

Number of Health Plans offered

Continue with Section B on MEPS-11(S)

500 Remarks 
Appendix B. Health Insurance Cost Study:

2010 Government Unit Questionnaire (11R) 


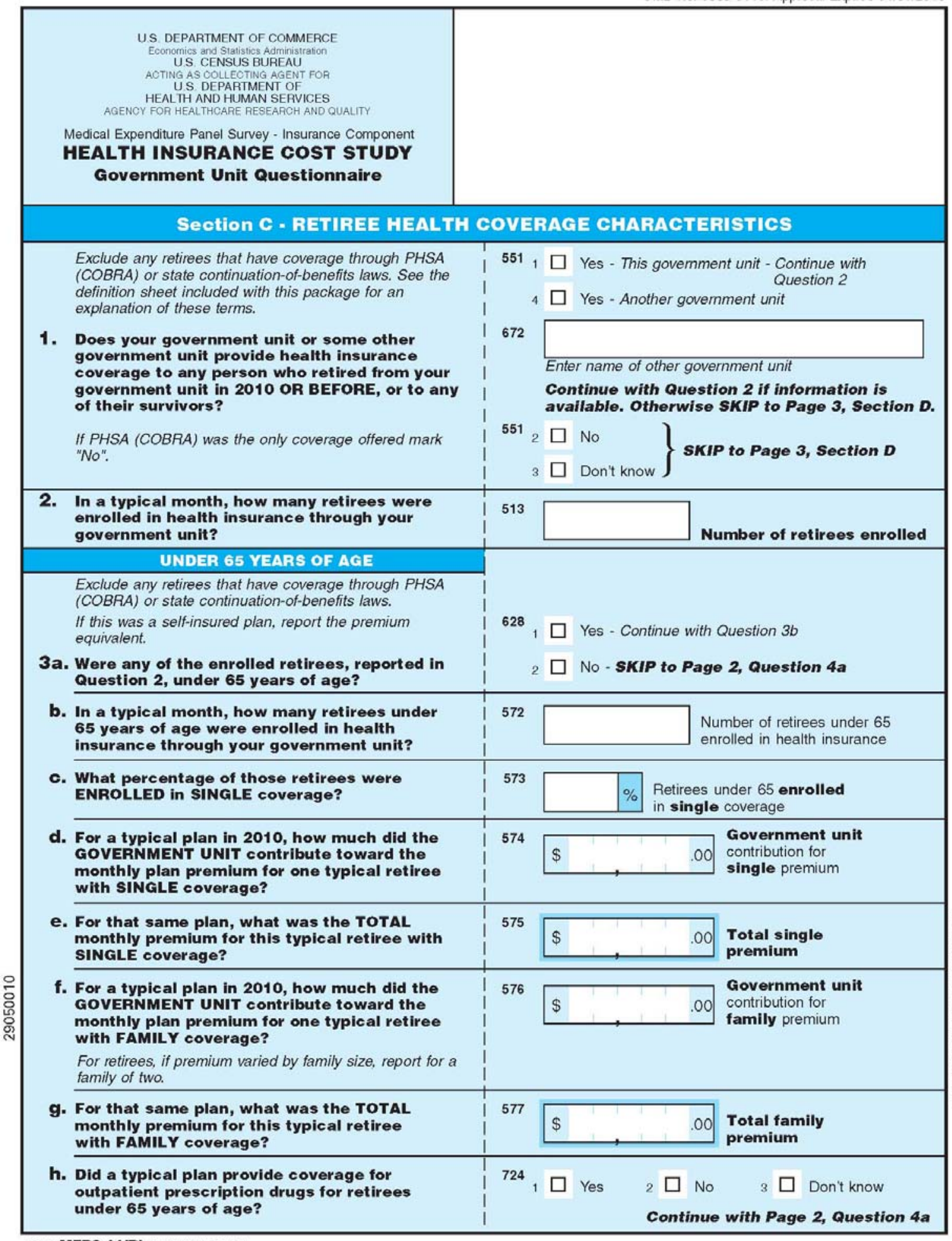

FORM MEPS-1 1(R) (04-07-2010) (Dratt 8) 


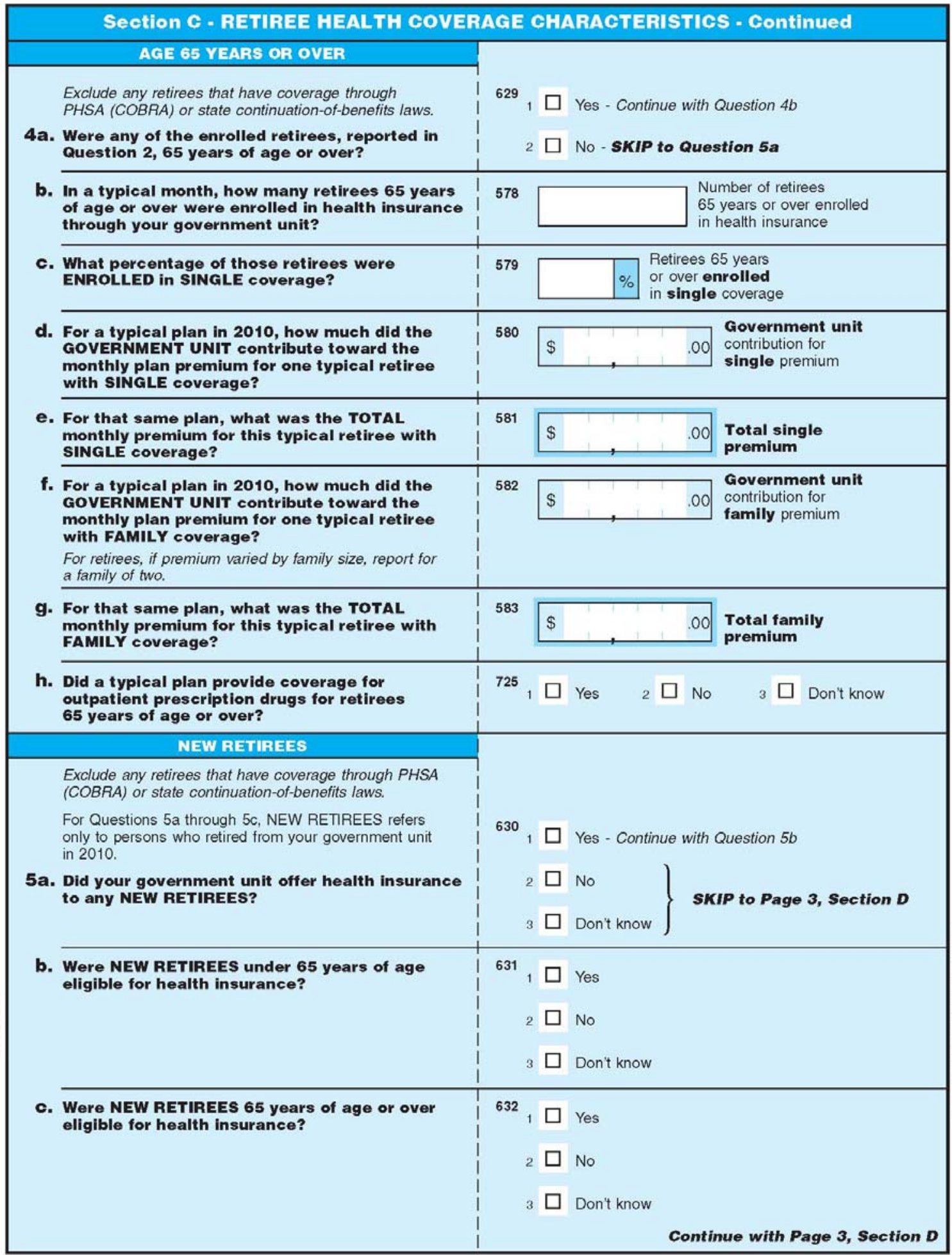

FOFM MEPS-1 1(R) (04-07-2010) (Dratit 8) 


\section{Section D - HEALTH GOVERAGE CHARACTERISTICS}
1a. Which of the listed optional coverage services, if any, did your government unit offer to its ACTIVE employees in 2010 at a premium SEPARATE from the comprehensive health plan premium?
Report single service insurance plans only.
Do not include single services covered under a comprehensive health plan.
Long-term care insurance helps to cover the cost of institutional and home care required by the chronically ill or disabled.
Mark $(X)$ all that apply.
b. What was the total amount paid for optional coverage for all ACTIVE employees at THIS GOVERNMENT UNIT during a typical month in 2010?

2a. For 2010, did your government unit impose a covered by health insurance?

b. For 2010, what was the typical waiting period? Mark $(X)$ only one. waiting period before new employees could be

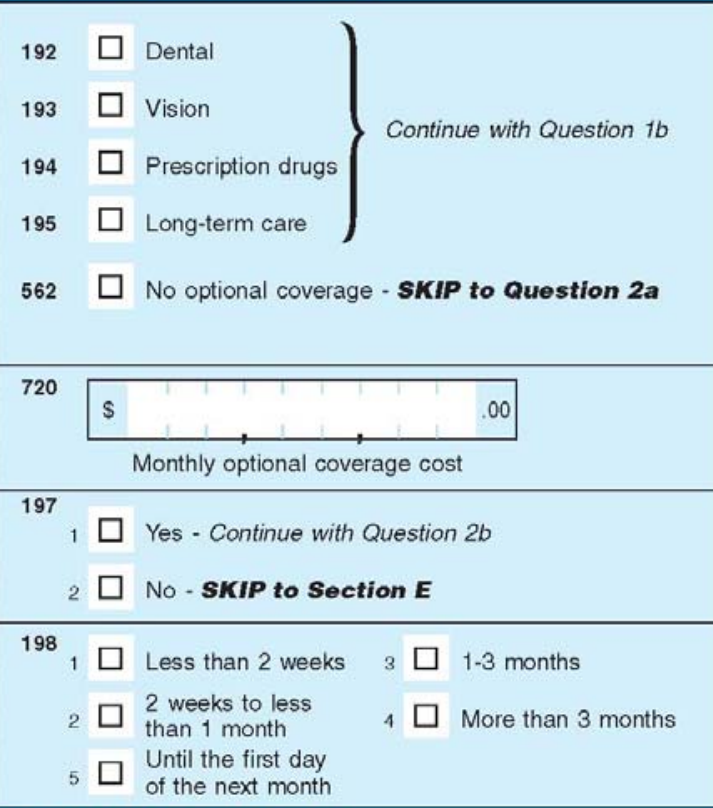

\section{Section E - EMPLOYMENT CHARAGTERISTICS}

Estimates are acceptable for all employment, eligibility, and enrollment figures

Include part-time, temporary, and seasonal employees. Exclude leased or contract workers and retirees.

1a. How many ACTIVE employees were ELIGIBLE for at least one health plan through your government unit for a typical pay period in 2010?

b. How many of those ACTIVE employees were ENROLLED in ANY health plan through your government unit?

2a. For the same typical pay period in 2010, did your government unit have any part-time employees?

b. How many of those part-time employees were ELIGIBLE for at least one health plan through your government unit?

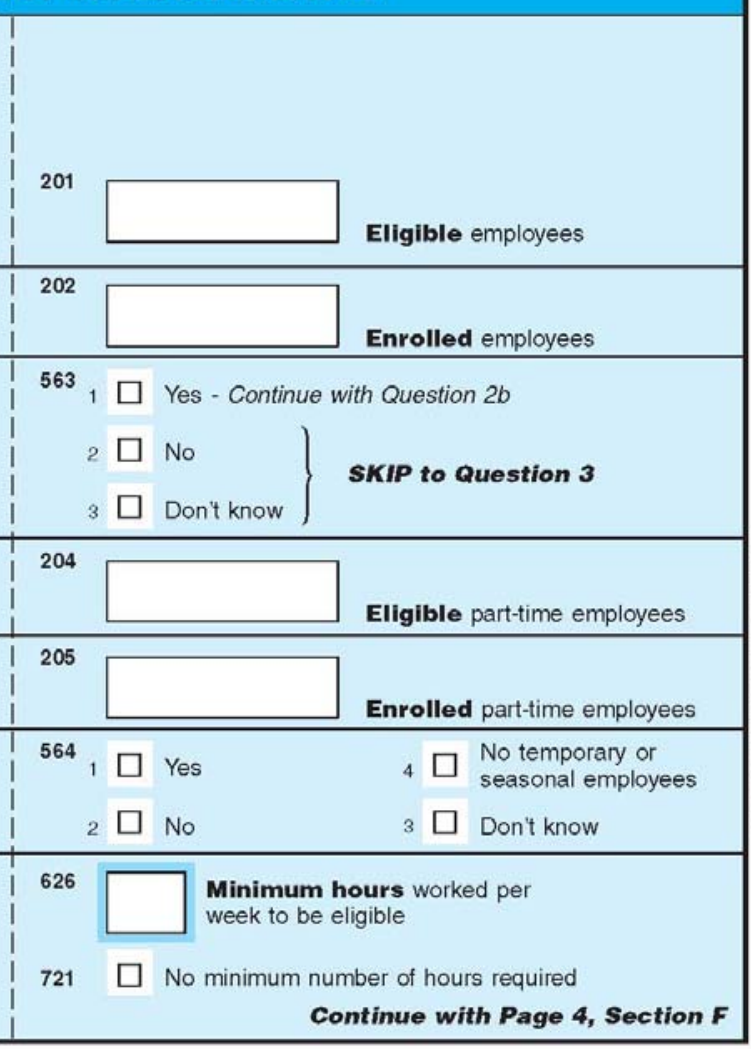

c. How many of those part-time employees were ENROLLED in ANY health plan through your government unit?

3. Did your government unit offer health insurance to its temporary or seasonal employees in 2010? Mark $(X)$ only one.

4. If your government unit offered health insurance, what is the minimum number of hours per week that an employee must work in order to be eligible for health insurance?

FORM MEPS-11 (R) (04-07-2010) (Dratt 8) 


\section{Section F - FRINGE BENEFITS GHARAGTERISTIOS}

1. Did your government unit offer the following fringe benefits to its employees in 2010?

2. Did your government unit offer any of these tax-advantaged benefits to its employees in 2010?

See the definition sheet included with this package for an explanation of these benefits.

These plans are also known as Section 125 Cafeteria Plans.

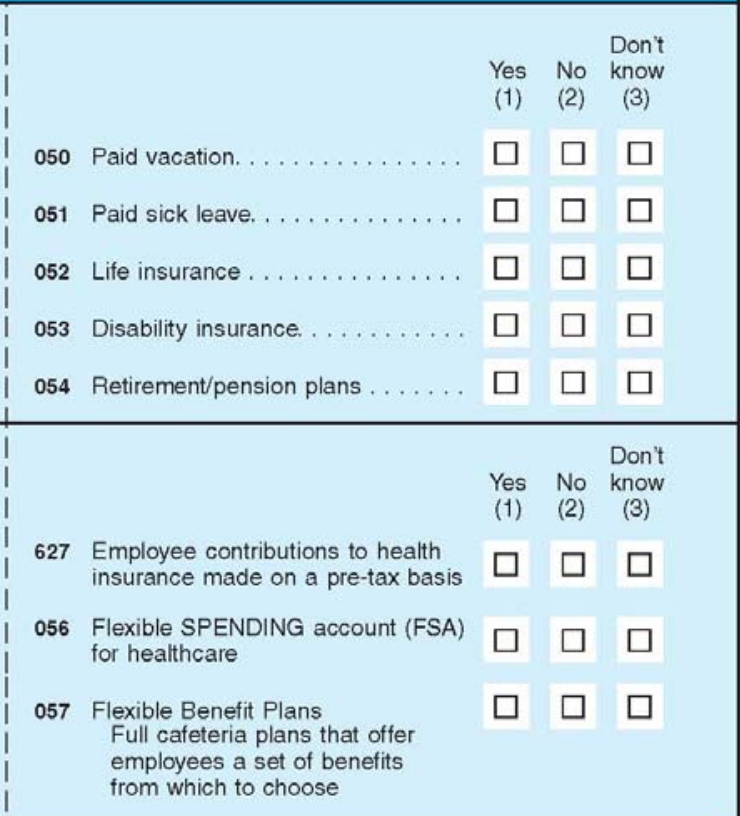

\section{Seotion G - EMPLOYEE GHARAGTERISTICS}

Provide information for a typical pay period in 2010.

Estimates are acceptable.

The following workforce characteristics are used to group similar government units together for analytical purposes.

If none, enter " $\mathrm{O}$.

1. Approximately what percentage of the employees at this government unit were women?

2. Approximately what percentage of the employees at this government unit were $\mathbf{5 0}$ years old or older?

3. Approximately what percentage of the employees at this government unit were union members?

4. For the employees at this government unit in 2010, approximately what percentage earned .

Less than $\$ 11.50$ per hour?

Approximately $\$ 23,920$ a year or less

Between $\mathbf{\$ 1 1 . 5 0}$ and $\mathbf{\$ 2 6 . 0 0}$ per hour? . . . . .

Approximately $\$ 23,920$ to $\$ 54,080$ a year

More than $\$ 26.00$ per hour?

Approximately $\$ 54,080$ a year or more

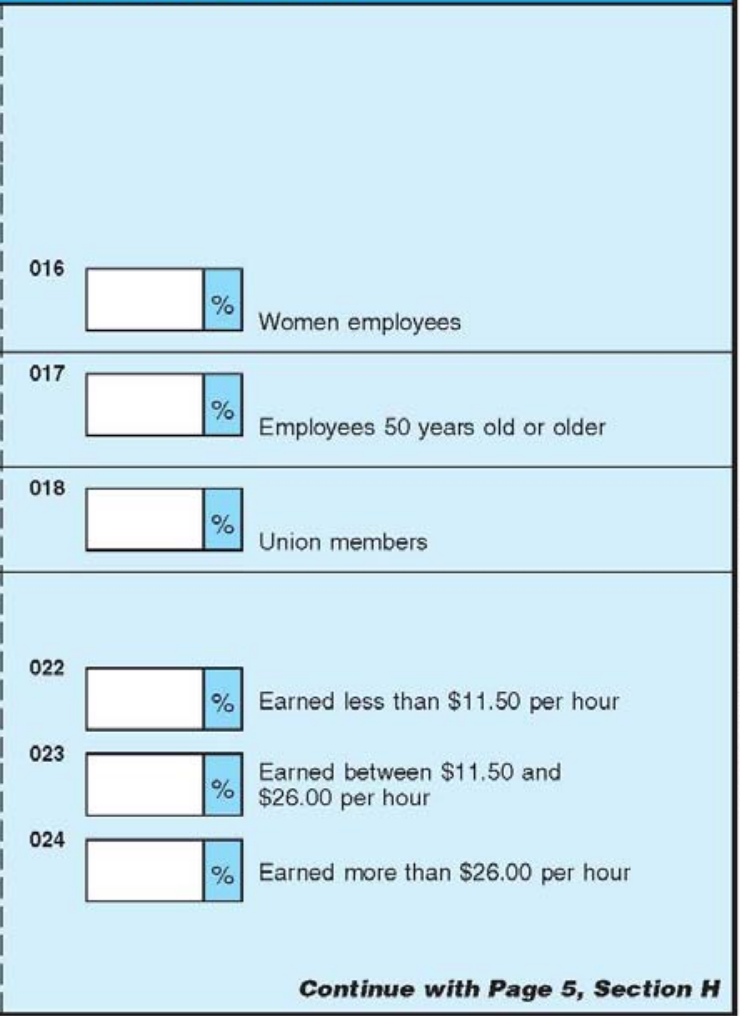

Continue with Page 5, Section H

FORM MEPS-1 1 (R) (04-07-2010) (Dratt 8) 


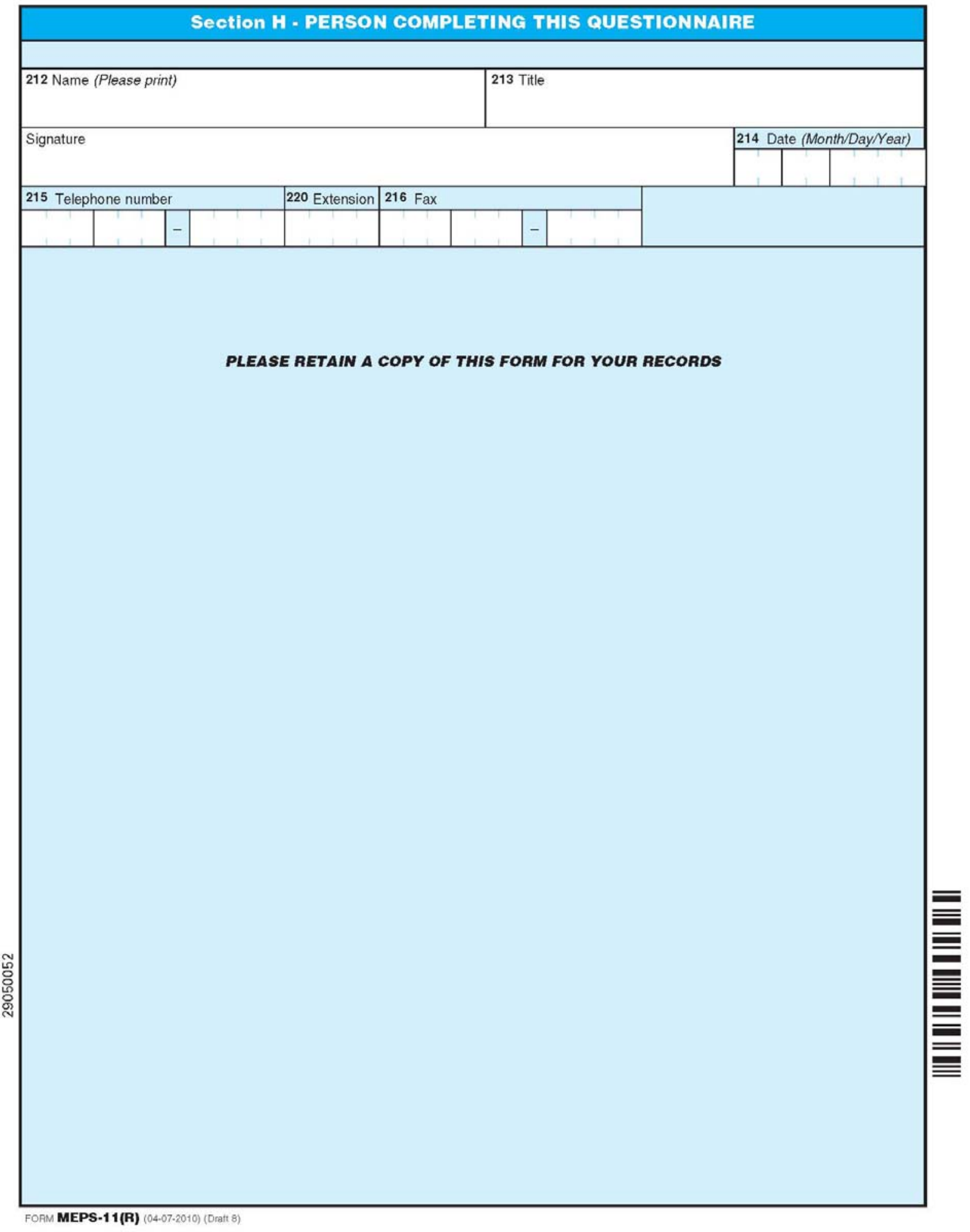


Appendix C. Health Insurance Cost Study:

2010 Plan Information Questionnaire (11S) 


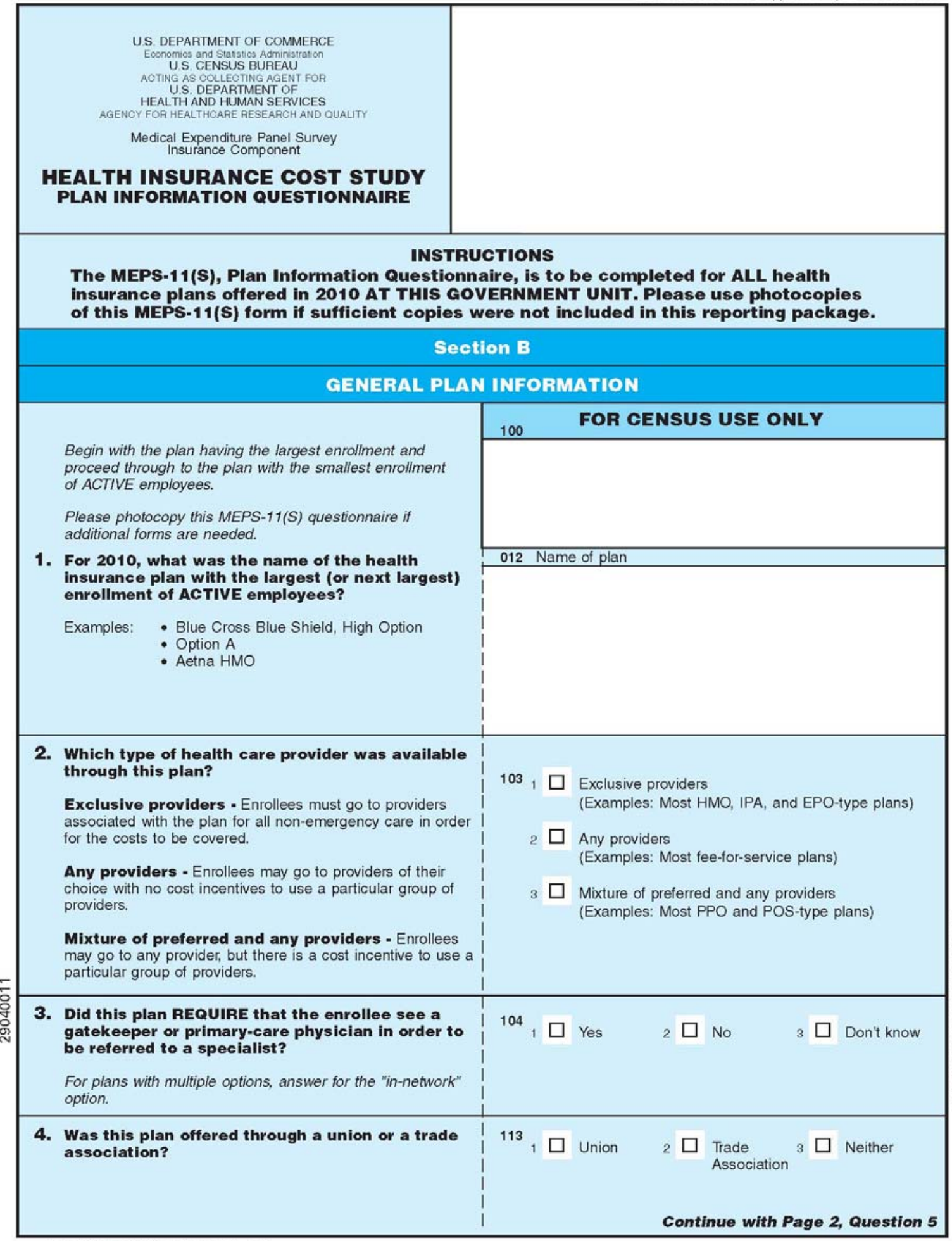

FORM MEPS-1 1(S) (04-07-2010) (Drall 8) 


\section{GENERAL PLAN INFORMATION - Continued}

5. Was this plan purchased from an insurance underwriter or was it self-insured?

Purchased from an insurance underwriter -

(Fully-insured) Coverage is purchased from an insurance company or other underwriter who assumes the risk for enrollees' medical expenses.

Self-insured - Your government unit assumes the risk for the enrollees' medical expenses and may charge a premium to employees. This plan may be administered by a third party and may employ supplemental stop-loss insurance to limit unanticipated losses.
105
$1 \square$ Purchased - SKIP to Question 7a
$2 \square$ Self-insured - Continue with Question 6a
$\square$ Don't know - SKIP to Question 7a

\section{SELF-INSURED PLAN INFORMATION}

Complete questions $6 a-b$ if this plan was self-insured.

6a. Did your government unit employ a Third Party Administrator (TPA) for this self-insured plan?

b. Did your government unit purchase stop-loss coverage for this plan?
713
$1 \square$ Yes - Used a Third Party Administrator
$2 \square$ No-Self-administered the plan
107 Yes
$2 \square$ No

\section{ACTIVE ENROLLMENT}

Estimates are acceptable for all enrollment figures,

7a. How many ACTIVE employees were ENROLLED in this plan at this government unit during a typical pay period in 2010?

Include full-time, part-time, temporary and seasonal employees.

Exclude retirees, former employees, leased or contract workers.

b. How many of those ACTIVE employees were ENROLLED in SINGLE coverage during a typical pay period in 2010 ?

EMPLOYEE-PLUS-ONE coverage is health insurance coverage for an employee-plus-spouse or an employee-plus-child(ren) AT A LOWER PREMIUM than family coverage

c. If your government unit offered

EMPLOYEE-PLUS-ONE coverage, how many ACTIVE employees were ENROLLED during a typical pay period in 2010 ?

Include enrollment for both employee-plus-spouse and employee-plus-child(ren) coverage.

d. How many of those ACTIVE employees were ENROLLED in FAMILY (not single or employee-plus-one) coverage during a typical pay period in 2010?

\section{PHSA (COBRA) ENROLLMENT}

8. How many FORMER employees were ENROLLED in this plan, excluding retirees, through PHSA (COBRA) or state continuation-of-benefits laws during a typical pay period in 2010 ?
125

129

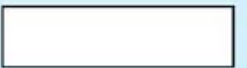

Active employees enrolled in single coverage

571

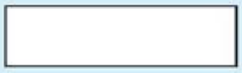

Active employees enrolled in employee-plus-one coverage

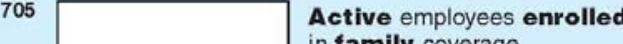
in family coverage

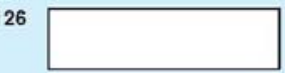

Former employees enrolled in plan, excluding retirees 


\section{PLAN PREMIUMS}

Report for TYPICAL situations and enrollees.

If this was a self-insured plan, report the premium equivalent.

If premium varied, report for a TYPICAL employee.

Report government unitemployee contributions and total premium for the same period in 2010.

Include any subsidy from an outside third party in the employee contribution for premiums.

If there is an HSA or HRA associated with this plan, include any employer contributions to an HSA or HRA account in the employer contribution for premiums.

\section{SINGLE COVERAGE}

$552, \square$ Yes - Continue with Question $9 b$

9a. Was SINGLE coverage offered under this plan?

b. For this plan, how much did the GOVERNMENT UNIT contribute toward the plan premium of one typical employee with SINGLE coverage?

c. How much did this typical EMPLOYEE with SINGLE coverage contribute toward his/her own premium?

d. What was the TOTAL premium for this typical employee with SINGLE coverage?

e. The amounts reported in questions $9 \mathrm{~b}-\mathrm{d}$ are based on which one of the following time periods?

Mark $(X)$ only one.

$2 \square$ No - SKIP to Question 10a

\begin{tabular}{|c|c|c|c|c|c|}
\hline 131 & $\$$ & & $\begin{array}{l}1.00 \\
\end{array}$ & \multicolumn{2}{|c|}{$\begin{array}{l}\text { Government unit } \\
\text { contribution for } \\
\text { single premium }\end{array}$} \\
\hline 132 & $\$$ & & .00 & \multicolumn{2}{|c|}{$\begin{array}{l}\text { Employee } \\
\text { contribution for } \\
\text { single premium }\end{array}$} \\
\hline 130 & $\$$ & & 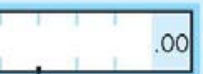 & \multicolumn{2}{|c|}{$\begin{array}{l}\text { Total single } \\
\text { premium }\end{array}$} \\
\hline 133 & 1 & $\square$ & Weekly & $5 \square$ & Quarterly \\
\hline & 2 & $\square$ & Every 2 weeks & ${ }_{4} \square$ & Yearly \\
\hline & 3 & $\square$ & Monthly & & \\
\hline
\end{tabular}

EMPLOYEE-PLUS-ONE COVERAGE

EMPLOYEE-PLUS-ONE coverage is health insurance coverage for an employee-plus-spouse or an employee-plus-child(ren) AT A LOWER PREMIUM LEVEL than family coverage.

If employee-plus-one premiums were different for employee-plus-child(ren) and employee-plus-spouse coverages, report for employee-plus-one child. If premiums varied for other reasons, report for a TYPICAL employee.

10a. Was EMPLOYEE-PLUS-ONE coverage offered under this plan?

b. For this plan, how much did the GOVERNMENT UNIT contribute toward the plan premium of one typical employee with EMPLOYEE. PLUS-ONE coverage?

c. How much did this typical EMPLOYEE with EMPLOYEE-PLUS-ONE coverage contribute toward his/her own premium?

$1 \square$ Yes - Continue with Question 10b

$2 \square$ No - SKIP to Page 4, Question 11a

Government unit

$\$$ contribution for

employee-plus-one premium

637 Employee

$\$ 37$ contribution for employee-plus-one

d. What was the TOTAL premium for this typical employee with EMPLOYEE-PLUS-ONE coverage?

e. The amounts reported in questions $10 \mathrm{~b}-\mathrm{d}$ are based on which one of the following time periods?

Mark $(X)$ only one.

\begin{tabular}{|c|c|c|c|c|c|c|}
\hline \multirow{2}{*}{$\begin{array}{r}635 \\
638\end{array}$} & 0 & & \begin{tabular}{|l|l|}
1 & .00 \\
\end{tabular} & \multicolumn{3}{|c|}{$\begin{array}{l}\text { Total } \\
\text { employee-plus-or } \\
\text { premium }\end{array}$} \\
\hline & 1 & $\square$ & Weekly & 5 & $\square$ & Quarterly \\
\hline & 2 & $\square$ & Every 2 weeks & 4 & $\square$ & Yearly \\
\hline & 3 & $\square$ & Monthly & & & \\
\hline
\end{tabular}

Continue with Page 4, Question 11a

FORM MEPS-1 1(S) (04-07-2010) (Dratt 8) 


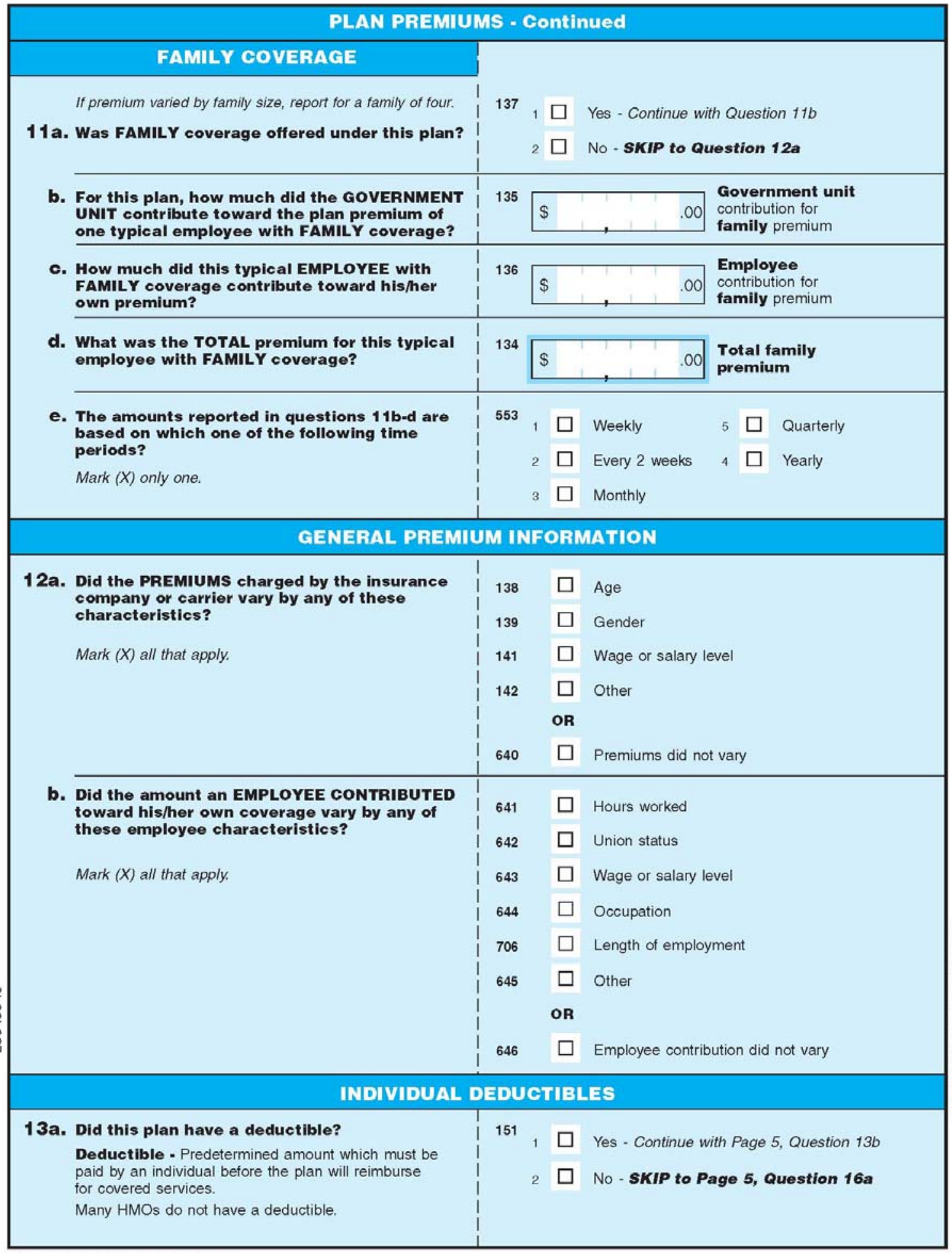

FOFM MEPS-1 1(S) (04-07-2010) (Dratt 8) 


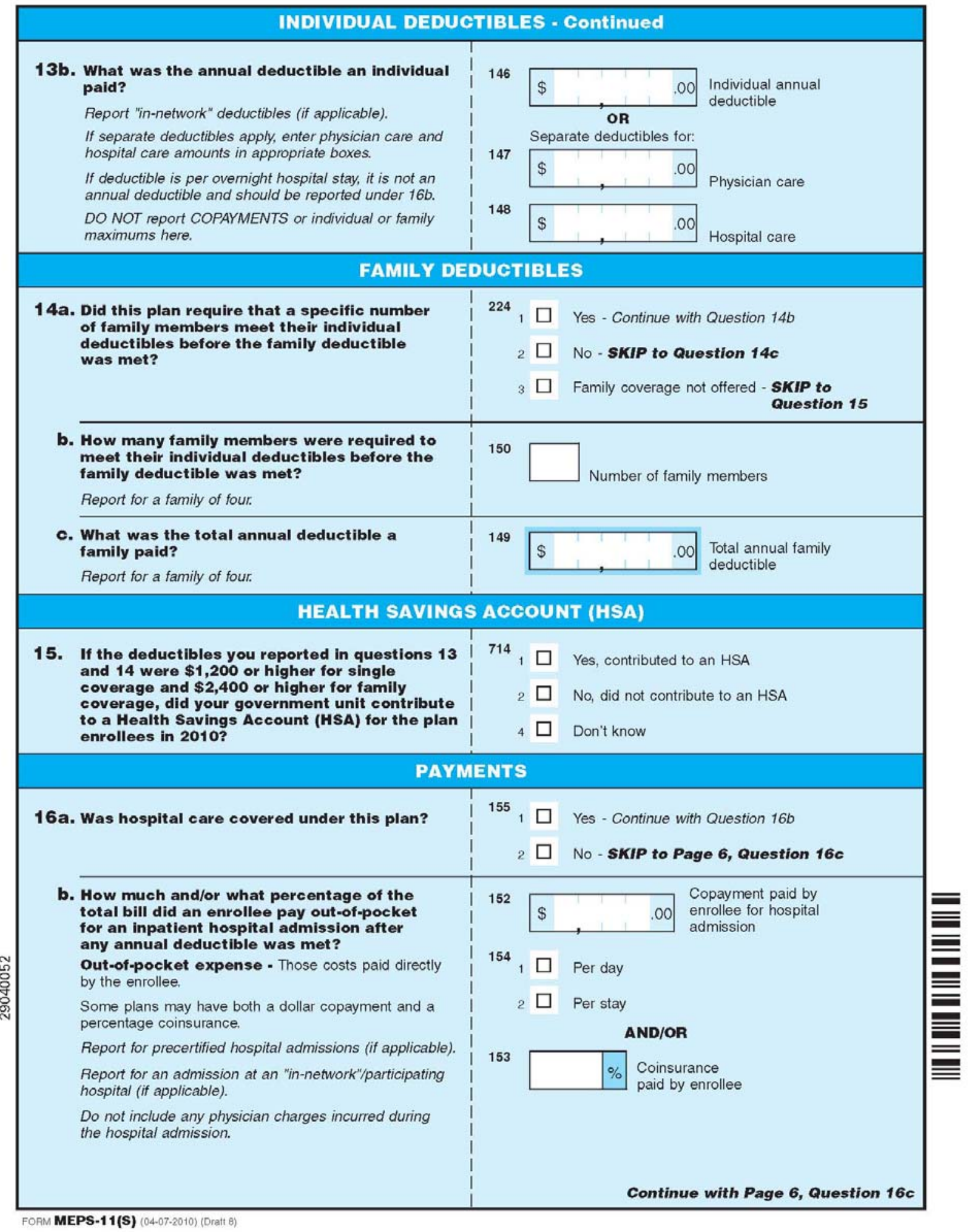




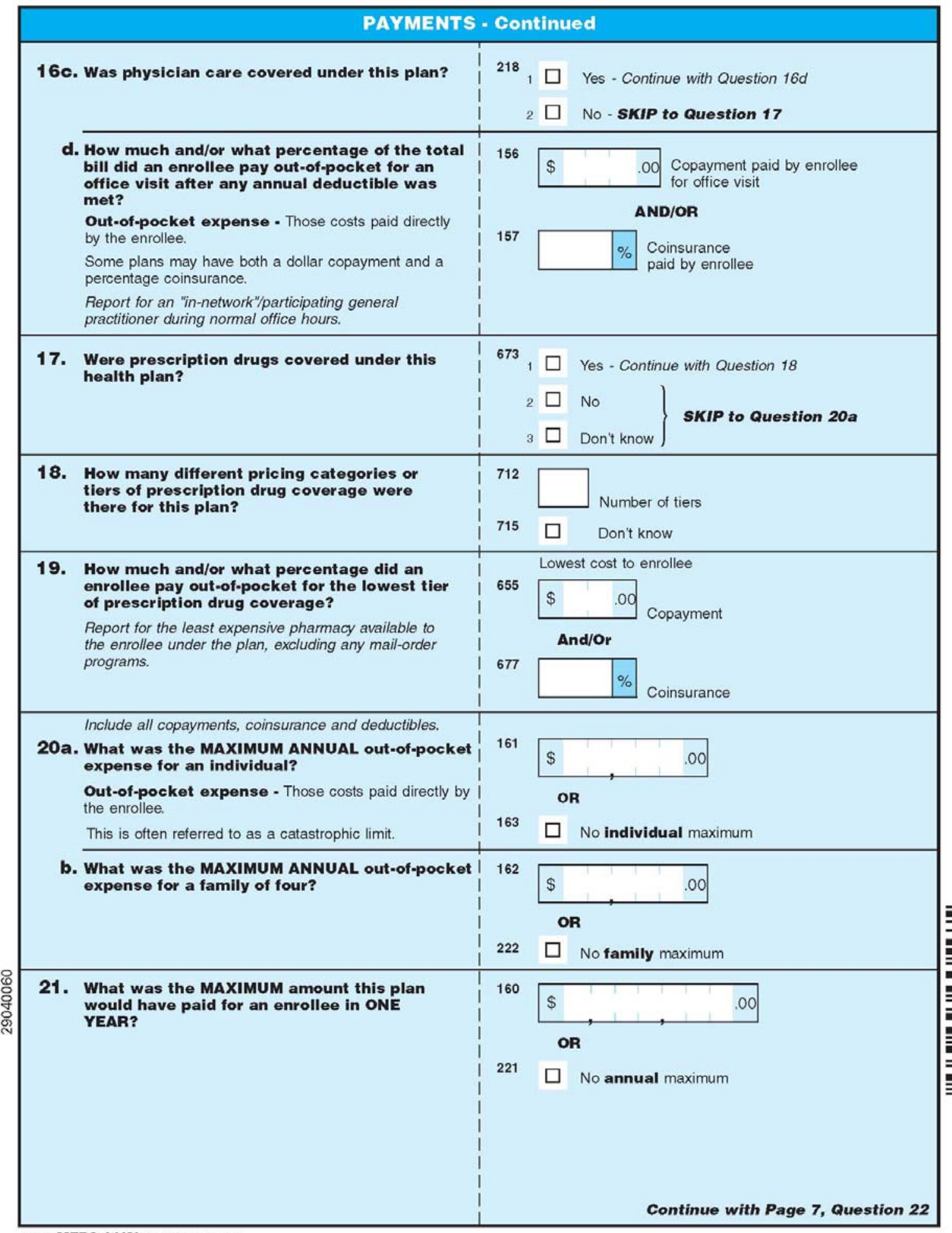

FOFM MEPS-1 1(S) (04-07-2010) (Dratt 8) 


\section{HEALTH REIMBURSEMENT ARRANGEMENT (HRA)}

22. An employer can offer a Health Reimbursement Arrangement (HRA) by setting up an account to reimburse employees for medical expenses not covered by health insurance. Did your

government unit offer an HRA associated with this plan in 2010?

HRAs are NOT Flexible Spending Accounts (FSAs)

or Health Savings Accounts (HSAs).

See definition sheet for more information.

\section{PLAN CHARACTERISTICS}

23. Could this plan have refused to cover persons with pre-existing medical or health conditions?

24. Did this plan have a policy requiring a waiting period before covering pre-existing conditions?

710

2

$3 \square$ Don't know this plan?

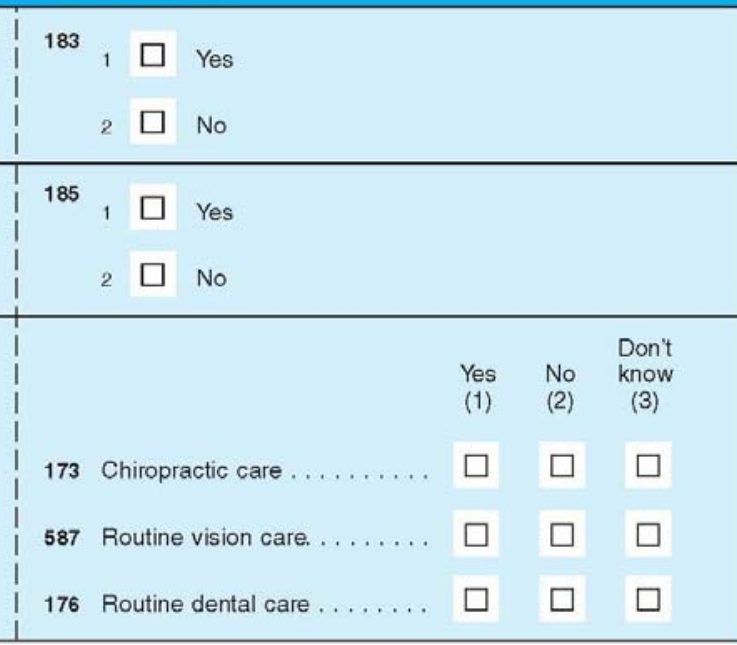

\section{$\star \star \star$ PLEASE NOTE $* \star \star$}

If your government unit offered MORE THAN ONE health insurance plan, please fill out a MEPS-11(S) for each plan that was offered. Then continue with the form MEPS-11(R), at the back of this package.

If this is your last health insurance plan, please continue with the form MEPS-11(R), Section C. 